\title{
Minimizing Trihalomethane Formation through Source Water Monitoring and Optimizing Treatment Practices
}

\author{
Nashid Mirza \\ West Virginia University, nm0070@mix.wvu.edu
}

Follow this and additional works at: https://researchrepository.wvu.edu/etd

Part of the Civil Engineering Commons, and the Environmental Engineering Commons

\section{Recommended Citation}

Mirza, Nashid, "Minimizing Trihalomethane Formation through Source Water Monitoring and Optimizing Treatment Practices" (2019). Graduate Theses, Dissertations, and Problem Reports. 7399.

https://researchrepository.wvu.edu/etd/7399

This Thesis is protected by copyright and/or related rights. It has been brought to you by the The Research Repository @ WVU with permission from the rights-holder(s). You are free to use this Thesis in any way that is permitted by the copyright and related rights legislation that applies to your use. For other uses you must obtain permission from the rights-holder(s) directly, unless additional rights are indicated by a Creative Commons license in the record and/ or on the work itself. This Thesis has been accepted for inclusion in WVU Graduate Theses, Dissertations, and Problem Reports collection by an authorized administrator of The Research Repository @ WVU. For more information, please contact researchrepository@mail.wvu.edu. 


\title{
Minimizing Trihalomethane Formation through Source Water
}

\section{Monitoring and Optimizing Treatment Practices}

\author{
Nashid Mirza
}

Thesis submitted

to the Benjamin M. Statler College of Engineering and Mineral Resources at West Virginia University

in partial fulfillment of the requirements for the degree of

Master of Science

in

Civil Engineering

Lian-Shin Lin, Ph.D., Chair

Antarpreet Jutla, Ph.D.

Paul Ziemkiewicz, Ph.D.

Department of Civil and Environmental Engineering

\author{
Morgantown, West Virginia
}

2019

Keywords: Water Quality, Disinfection by product, Trihalomethane

Copyright 2019 Nashid Mirza 


\section{ABSTRACT \\ Minimizing Trihalomethane Formation through Source Water Monitoring and Optimizing Treatment Practices \\ Nashid Mirza}

Trihalomethanes, a family of halogenated disinfection byproducts, are prevalent in finished drinking water. According to USEPA's Disinfectants and Disinfection Byproducts Rules (DBPRs), the regulatory standard of the total trihalomethanes (TTHMs) is $80 \mu \mathrm{g} / \mathrm{L}$, and water treatment plant operators are required to closely monitor TTHMs in the finished water on a quarterly basis. Although total organic carbon (TOC) has been identified as a precursor for the TTHMs, knowledge gaps still exist in how specific water and treatment related factors (e.g., intake water quality, seasonal variation, contact time, and treatment train) affect TTHMs formation. Focusing on water treatment plants in southwestern Pennsylvania, the objectives of this study include 1) developing a predictive statistical model for TTHMs level using source water quality data, and 2) analyzing the effects of water treatment and distribution factors on TTHMs formation. Water quality data were collected through monthly sampling at three water authorities and five distribution points from September 2018 to May 2019. These data were used to explore statistical relationships between intake water quality and TTHMs formation in the distribution systems. Two regression models were developed to predict TTHMs level using relevant water quality parameters including TOC, chloride, and temperature. Based on the analysis, the TOC level at the intake water greatly impacted the TTHMs formation, and the TTHMs level was higher during September and October when the temperature and TOC levels were elevated. With low bromide (mostly undetected) in the source water, the THM species in the finished water were dominated by the 
chlorinated species. A comparison between the predicted and measured TTHMs data showed that, in most cases, the error was greater than $10 \%$. This is attributed to the effects of plant specific treatment operation on TTHMs formation. To achieve the second objective, analyses were conducted using the treatment related data collected from the Borough of Charleroi Water Authority. It was observed that installation of a sedimentation basin helped to reduce the TTHMs level. Based on these findings, recommendations are provided to reduce TTHMs including introducing alternative disinfectant, maintaining minimum retention time, and flushing low demand distribution networks. 


\section{ACKNOWLEDGEMENTS}

I would like to express my sincere gratitude to my supervisor, Dr. Lian-Shin Lin, for his continuous and valuable guidance, counselling and inspiration throughout my graduate research work. Without his active interest, it would not have been possible for me to complete my research. I would like to thank Dr. Antarpreet Jutla and Dr. Paul Ziemkiewicz for being my thesis committee members and providing me with their utmost advice, support and encouragement.

This work was ostentatiously supported by the West Virginia Water Research Institution and United States Geological Survey funding. I would like to thank Melissa O’Neal and Benjamin Pursglove from the West Virginia Water Research Institution for their great collaboration.

I would like to dedicate my thesis to my parents whose unconditional love and support made me who I am today. To my sister who helped me to maintain my sanity during the stressful times.

Lastly, I would like to thank my husband Shofiq whose immense support and encouragement throughout these past two years were laudable. 


\section{Table of Contents}

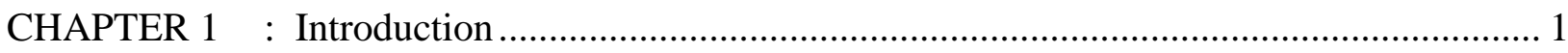

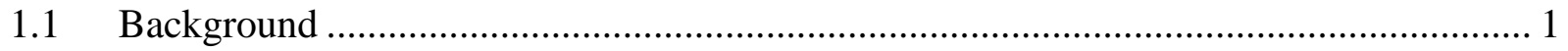

$1.2 \quad$ Problems Scope and Objective .................................................................................. 3

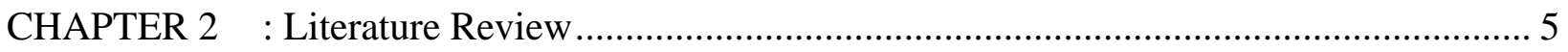

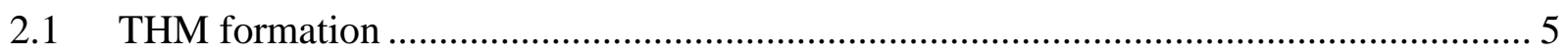

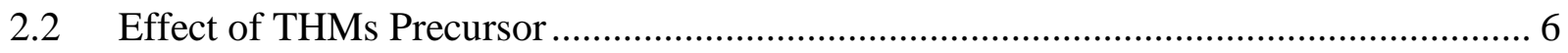

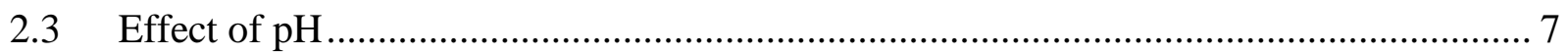

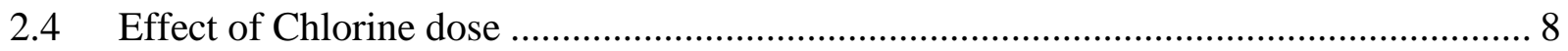

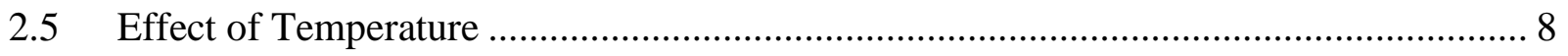

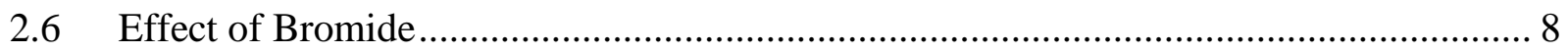

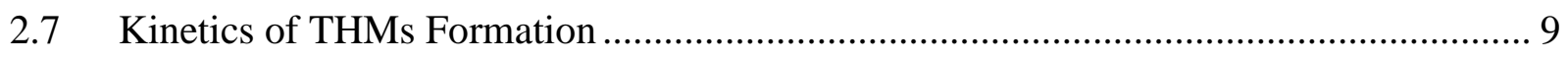

2.8 Effects of Treatment Processes on THMs formation ................................................... 10

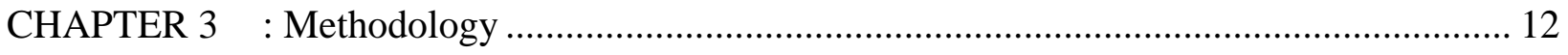

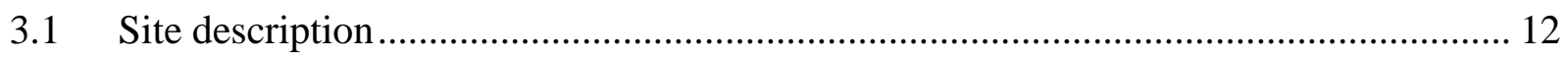

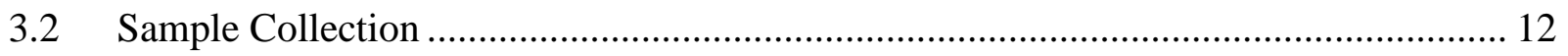

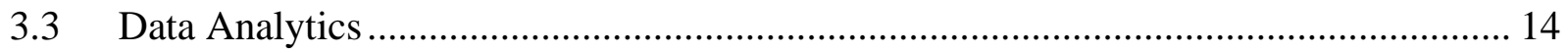

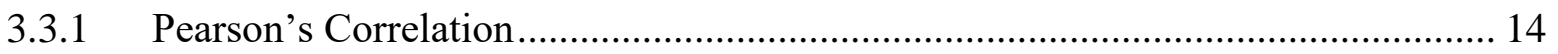

3.3.2 Regression Based Model..................................................................................... 14

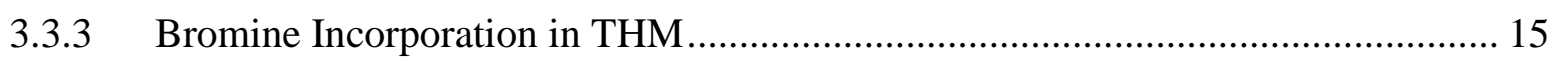

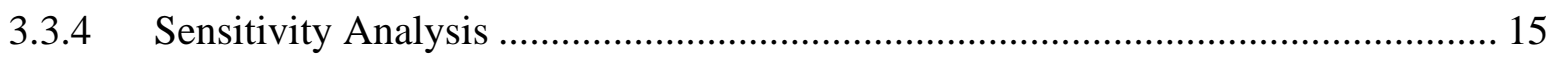

3.4 Borough of Charleroi Treatment Practices................................................................ 16 
CHAPTER $4 \quad$ : Results and Discussion........................................................................ 19

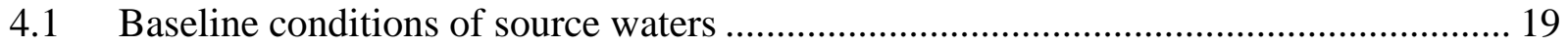

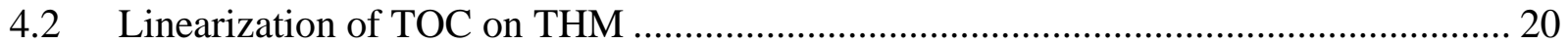

4.3 Distribution of THM species ......................................................................... 23

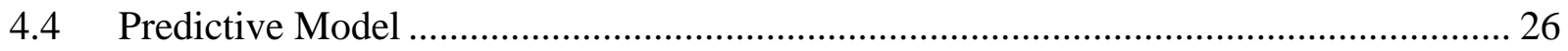

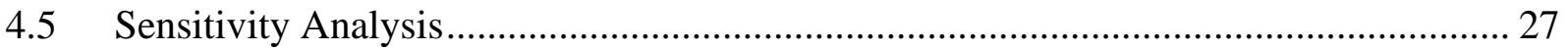

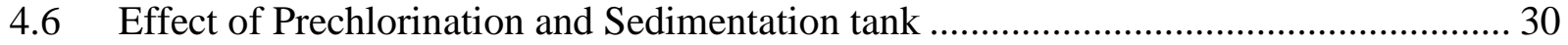

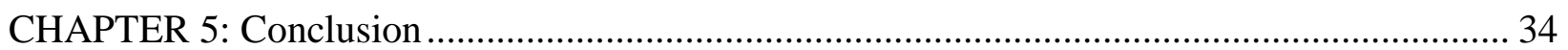

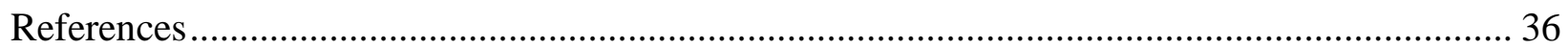




\section{List of Figures}

Figure 2-1: Distribution of main free chlorine species as a function of $\mathrm{pH}$ at $25^{\circ} \mathrm{C}$ for chloride

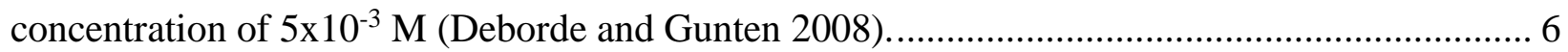
Figure 2-2 Correlation of the percentage of brominated THMs in Pittsburgh Water and Sewer Authority's finished water and bromide concentrations at the intake in Allegheny River (States et al. 2013) 9

Figure 2-3: Illustration of removal of NOM fractions by various pretreatment processes adopted from Bergman (2016). 11

Figure 3-1: Sampling locations for the studied water treatment plants and distribution networks. 13

Figure 3-2: Schematic of Charleroi water treatment plant 17

Figure 4-1: TOC concentration in the source waters vs TTHMs in the finished water at the three water treatment plants (September 2018 to May 2019) 21

Figure 4-2: Variations in TOC level of intake water with monthly temperature........................ 22

Figure 4-3: TTHM levels in the distribution networks (September 2018-May 2019) ............... 23

Figure 4-4 : Distribution of trihalomethane species in the finished water samples.................... 24

Figure 4-5: (Top) changes in BSF and \% brominated by mass with the source bromide level, and (Bottom) changes in TTHMs with BSF and \% brominated by mass. 25

Figure 4-6: Measured TTHMs vs the predicted TTHMs concentration for linear regression...... 26 Figure 4-7: Measured TTHMs vs the predicted TTHMs concentration for nonlinear regression. 27 Figure 4-8: Monte Carlo simulations of THMs values falling outside of specifications limits (Left) for linear regression model and (Right) nonlinear regression model. 28 
Figure 4-9: Sensitivity of the output standard deviation to the predictor variables for linear

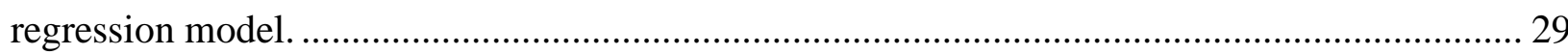

Figure 4-10: Sensitivity of the output standard deviation to the predictor variables for the nonlinear

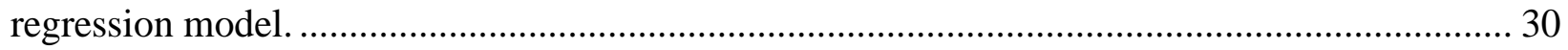
Figure 4-11: Effects of Chlorination in THM formation at the Borough of Charleroi Water

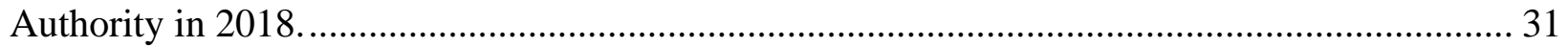
Figure 4-12: Comparison of TTHMs in the distribution network and TOC concentration in raw water before and after the installation of sedimentation tanks. 32 


\section{List of Tables}

Table 1-1: Regulated contaminant levels by the Stage 1 and Stage 2 DBPR Rule (USEPA 2006)

Table 2-1: Psuedo first-order rate constants (K) for THMs formation at various temperature and activation energies (Masoud, Ismail, and El-Hoshy 2019) .................................................. 10

Table 4-1: Seasonal averages and standard deviations of source water quality parameters......... 19

Table 4-2: Correlation matrix for source water quality parameters...................................... 20

Table 4-3: Summary statics of the Monte Carlo simulation outputs of the two models. ........... 28 


\section{CHAPTER 1 : INTRODUCTION}

\subsection{Background}

The practice of drinking water disinfection to remove pathogens is considered as one of the greatest achievements of the 20th century. Chlorine has been used as the principal disinfectant since the evolution of this technique. However, the discovery of chloroform by Rook in the early 1970s, arose a great concern for the unintended public health hazard of disinfection by-products (DBPs, Rook 1974). The ongoing concern for chlorination is the formation of trihalomethanes (THMs), a family of DBPs including chloroform, bromodichloromethane, dibromochloromethane, and bromoform. Studies have shown increased risks of bladder cancer, rectal cancer, mutagenicy, and retardation of fetal growth in human because of exposure to THMs (Villanueva et al. 2004; Cantor et al. 1998; Bove, Rogerson, and Vena 2007; Wright, Schwartz, and Dockery 2003). Due to such associated risks, the United States Environment Protection Agency (USEPA) established THMs standard of $100 \mu \mathrm{g} / \mathrm{L}(\mathrm{ppb})$ in 1979. Later on, the first and second stage Disinfectants and Disinfection Byproducts Rules (DBPRs) were promulgated by USEPA to reduce exposure to BDPs in 1998 and 2006 respectively ( USEPA 1998;USEPA 2006). In 2002, the DBPR affected the routine monitoring of surface water treatment plants serving at least 10,000 people. Small plants were required to monitor at locations with the highest DBPs based on initial distribution system evaluation starting in the first quarter of 2004. The USEPA's Drinking Water Standards have set a maximum contaminant level (MCL) for total trihalomethanes (TTHMs) at $80 \mu \mathrm{g} / \mathrm{L}$ in 2006 using locational running annual averages (LRAAs). In addition, a stringent maximum contaminant level goal (MCLG) for chloroform and dibromochloromethane are required to be maintained (Table 1-1). Other regulated BDPs include five haloacetic acids (HAA5), bromate and 
chlorite. There are established maximum residual disinfection level goals (MRDLGs) and enforceable maximum residual disinfectant level (MRDL) standards for three chemical disinfectants-chlorine, chloramine, and chlorine dioxide. Under DBPR stage 1 and stage 2, there is also a requirement for total organic carbon removal (TOC).

Table 1-1: Regulated contaminant levels by the Stage 1 and Stage 2 DBPR Rule (USEPA 2006)

\begin{tabular}{|c|c|c|}
\hline Regulated Contaminants & MCL $(\mathrm{mg} / \mathrm{L})$ & $\operatorname{MCLG}(\mathbf{m g} / \mathrm{L})$ \\
\hline TTHM & 0.08 & \\
\hline Chloroform & & 0.07 \\
\hline Bromodichloromethane & & Zero \\
\hline Dibromochloromethane & & 0.06 \\
\hline Bromoform & & Zero \\
\hline HAA5 & 0.06 & \\
\hline Bromate (plants that use ozone) & 0.01 & Zero \\
\hline $\begin{array}{l}\text { Chlorite (plants that use chlorine } \\
\text { dioxide) }\end{array}$ & 1 & 0.80 \\
\hline Regulated Disinfectants & MRDL (mg/L) & MRDLG (mg/L) \\
\hline Chlorine & 4.0 as $\mathrm{Cl}_{2}$ & 4 \\
\hline Chloramines & 4.0 as $\mathrm{Cl}_{2}$ & 4 \\
\hline Chlorine dioxide & 0.8 & 0.8 \\
\hline
\end{tabular}

Past monitoring of THMs has shown that violations in drinking water systems are prevalent in the United States. A study on nationwide health-based violations in 17,900 community water systems during 1982- 2015 indicated that out of total 95,754 violations, most prevalent violations were caused by total coliforms and DBPs (Allaire et al. 2018). Another report of EPA stated that 3508 
community water systems were out of compliance with the health based standards during 2017, of which $31 \%$ were attributed to violation of stage 2 DBPR rule (Thompkins 2018). It is evident that community water systems are struggling to maintain the MCL of TTHMs and/or maximum residual of disinfectant according to the Stage 2 BDPR rule. Although treatment plant operators often encounter TTHMs levels above the $80 \mu \mathrm{g} / \mathrm{L}$ primary drinking water standard, workable guidelines for reducing THM levels are not available.

Trihalomethane removal strategies can be categorized in three approaches: a) removal of the DBPs precursor b) modifications and optimization of treatment and disinfection practices to minimize THMs formation and c) removal of DBPs after formation. The formation of THMs in treated drinking water is highly influenced by source water quality. Various water quality parameters such as natural organic matter (NOM), temperature, chlorine dose and residual, contact time, and bromide concentration have been found to greatly impact the THMs formation (Singer 1994).Higher bromide levels favor the formation of brominated trihalomethanes over the chlorinated trihalomethanes (Xue et al. 2014) which are even more carcinogenic than chlorinated analogs (Richardson 2003).

\subsection{Problems Scope and Objective}

Building upon the Three River Quest (3RQ) study conducted by the West Virginia Water Research Institute (WVWRI), this study focused on investigating THMs occurrences, violations, and formation potential in three mid-size water authorities in Southwestern Pennsylvania. WVWRI has previously monitored all these three intakes and examined the water quality trends. This study continued and expanded the previous monitoring program by supplementing the earlier data with the recent measurement of THM precursor's levels in the source waters of the treatment plants. 
The study had a two-folded objective: 1) development of predictive models for THMs levels in the finished waters using source water quality parameters, and 2) evaluation of the treatment process effects on THMs formation.

To achieve the first objective, we examined relationships between the source water and finished water quality. The data were then used to develop statistical models to predict THMs levels in finished water using source water quality parameters. Two multivariate regression models (i.e., linear and nonlinear) were developed. A comparison between the predicted THMs levels with the observed values was conducted for the two models. The relative importance of the predicting variables of the models was evaluated by conducting sensitivity analysis utilizing Monte Carlo simulations.

To achieve the second objective, the effects of water treatment operation and distribution on THMs formation were examined. Specifically, historical treatment related data were collected from a water authority to investigate how changes in the treatment practices previously had affected THMs formation. We had also exchanged the knowledge of THMs formation and treatment practices with the water authority and developed recommendations for THMs reduction. 


\section{CHAPTER 2 : LITERATURE REVIEW}

\subsection{THM formation}

Trihalomethanes form when chlorine used as disinfectant in water treatment from reacting with natural organic matter (NOM) in the source water or distribution system. The rate and distribution of THMs formation primarily depend on the source water characteristics and conditions of disinfection. The inherent chemical properties such as type and abundance of both organic and inorganic precursors in the source water play a significant role in controlling the concentration and speciation of trihalomethanes. Disinfection conditions such as contact time, $\mathrm{pH}$, temperature, dosages, and residual chlorine concentration are important as well (Singer 1994).

When chlorine is dissolved in water it undergoes the following hydrolysis reaction (Fair et al. 1949):

$$
\mathrm{Cl}_{2}+\mathrm{H}_{2} \mathrm{O} \leftrightarrow \mathrm{HOCl}+\mathrm{H}^{+}+\mathrm{Cl}^{-}
$$

This rate of reaction is so rapid that it takes very few seconds to complete this hydrolysis even in ordinary temperature (reference). The oxidizing capacity is basically retained in $\mathrm{HOCl}$, hypochlorous acid. This acid goes through acid dissociation as follows:

$$
\mathrm{HOCl} \leftrightarrow \mathrm{H}^{+}+\mathrm{OCl}^{-} \quad p k_{a}=7.4-7.8
$$

The acid dissociation constant $(\mathrm{pKa})$ of hypochlorous acid is approximately 7.5 (Carrell Morris et al. 1922), which is close to the $\mathrm{pH}$ of many natural waters. But whenever the $\mathrm{pH}$ of water increases, the percentage of free chlorine in the form of $\mathrm{HOCl}$ decreases. The distribution of $\mathrm{Cl}_{2}, \mathrm{HOCl}$ and $\mathrm{OCl}^{-}$as a function of the $\mathrm{pH}$ at $25^{\circ} \mathrm{C}$ is shown is Figure 2-1 for a chloride concentration of $5 \times 10^{-3}$ M. 


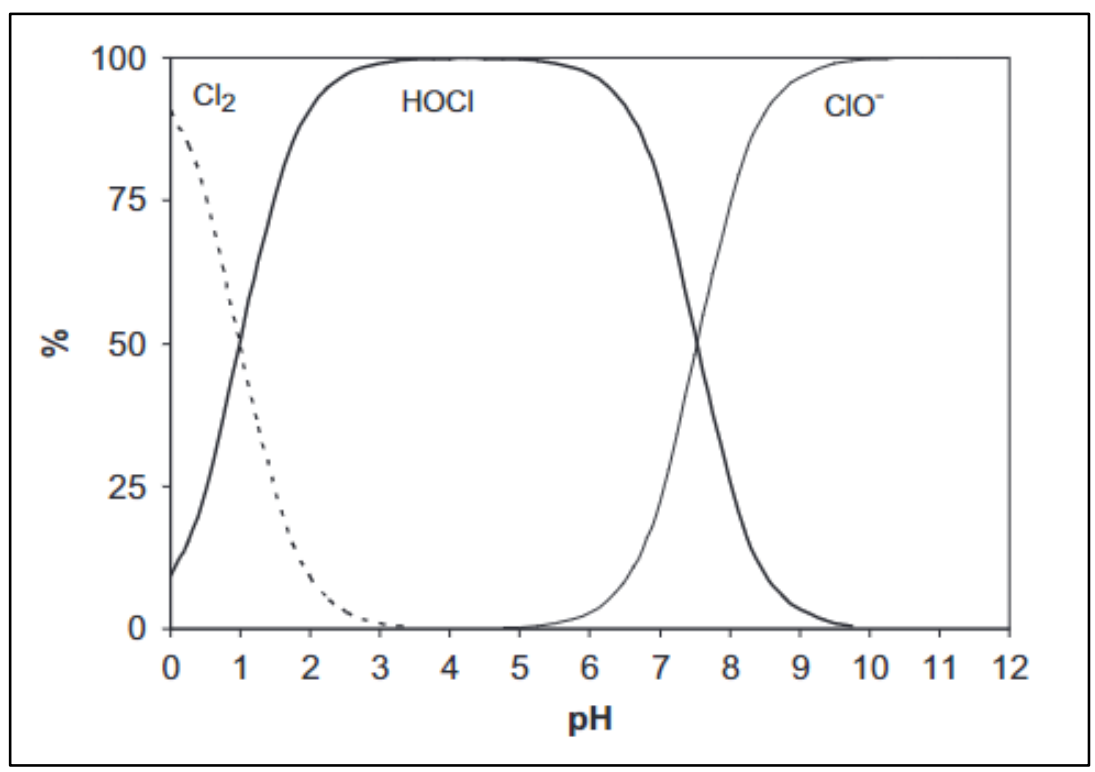

Figure 2-1: Distribution of main free chlorine species as a function of $\mathrm{pH}$ at $25^{\circ} \mathrm{C}$ for chloride concentration of $5 \times 10^{-3} \mathrm{M}$ (Deborde and Gunten 2008).

\subsection{Effect of THMs Precursor}

NOM is a heterogenous mixture of complex organic matters that are present in surface water. The typical chlorine reaction with NOM can be presented as:

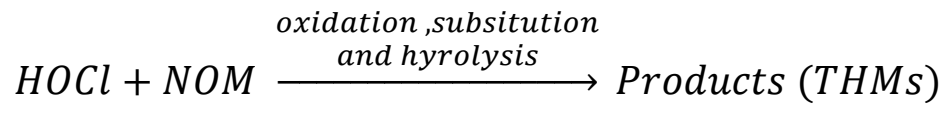

The possible reactions of hypochlorous acid with organic compounds can occur in three ways: (i) oxidation, (ii) addition to unsaturated bonds and (iii) electrophilic substitution reaction at nucleophilic sites (Deborde and Gunten 2008).

The NOM levels in the water generally measured as either total organic carbon (TOC) or dissolved organic carbon (DOC). NOM can be fractionated into humic acid and fulvic acids. Babcock and Singer (1979) chlorinated both humic and fulvic acid to examine their reactivity for THMs 
formation. Humic acid was found to be more reactive than the fulvic acid and yielded more chloroforms. A Study by Croué (2004) showed that the largest fraction of NOM corresponded to the humic materials. This humic material can further be fractionated based on their hydrophobic/hydrophilic character. When the water contained more hydrophilic carbon which had larger portion of aliphatic moieties than hydrophobic carbon, chlorination yielded more THMs. The author also developed a linear regression model using TOC values and found that total TOC in the river samples did not appear as a significant parameter for predicting THMs. The reason behind this anomality was attributed to the fact that the chemical composition of different organic matter fractions plays a more significant role than the amount of TOC for THM formation. In natural water, NOM variables are difficult to control from the management perspective and therefore, special attention needs to be paid to the natural variation of the compositions of NOM due to seasonal changes.

\subsection{Effect of $\mathrm{pH}$}

Hypochlorous acid is much stronger oxidizing agent than hypochlorite ion. The disinfection efficiency of chlorine decreases markedly with increase in $\mathrm{pH}$ when the hypochlorite ion becomes dominating species. In an experiment conducted by Nikolaou (2004), the bromine incorporation factor (BIF) for THMs was almost constant during $\mathrm{pH}$ range of 4-9. But $\mathrm{pH}>9$ resulted in a significant BIF factor decrease, and this can be explained as a result of the transformation free chlorine to less the reactive hypochlorite ion. Liang and Singer (2003) reported that change of $\mathrm{pH}$ from 6 to 8 resulted in higher THMs levels and the formation increased with contact time. 


\subsection{Effect of Chlorine dose}

Chlorine dose used in water treatment plants is estimated by the chlorine demand of the water and residual chlorine expected to be present in the distribution water. Increase of chlorine dose was found to enhance THM formation to a certain maximum amount until the TOC was totally oxidized by chlorine (Zhang et al. 2012). Thus, the chlorine demand is a better surrogate than the chlorine dose to predict THMs formation regardless of water sources. The chlorine demand-THMs formation relationship was reported to be affected by algal driven carbon (Padhi et al., 2019).

\subsection{Effect of Temperature}

In general, THMs formation has a positive correlation with temperature (Huang, Chen, and Wang 2019; Hua and Reckhow, 2008). However, the BDP formation was found decreased if the water was incubated at higher temperature before chlorination, which was attributed to increased microbial activity leading to more degradation of organic precursors (Huang, Chen, and Wang, 2019).

\subsection{Effect of Bromide}

Presence of bromide in the water, shifts the formation of hypochlorous acid to the hypobromous acid which in same manner produces hypobromite ion and brominated organic compounds from reacting with NOM. Though naturally the level of bromide is very low in river water, wastewater produced from industries such as shale gas development, coal-fired plants, steel mills dumped in river can cause increase in bromide levels. States et al. (2013) detected levels of bromide higher than $200 \mu \mathrm{g} / \mathrm{L}$ at the intake of the Pittsburgh Water and Sewer Authority plant in Allegheny River during year 2010-2011 and reported the formation potential of brominated THMs using the samples (Figure 2-2). 


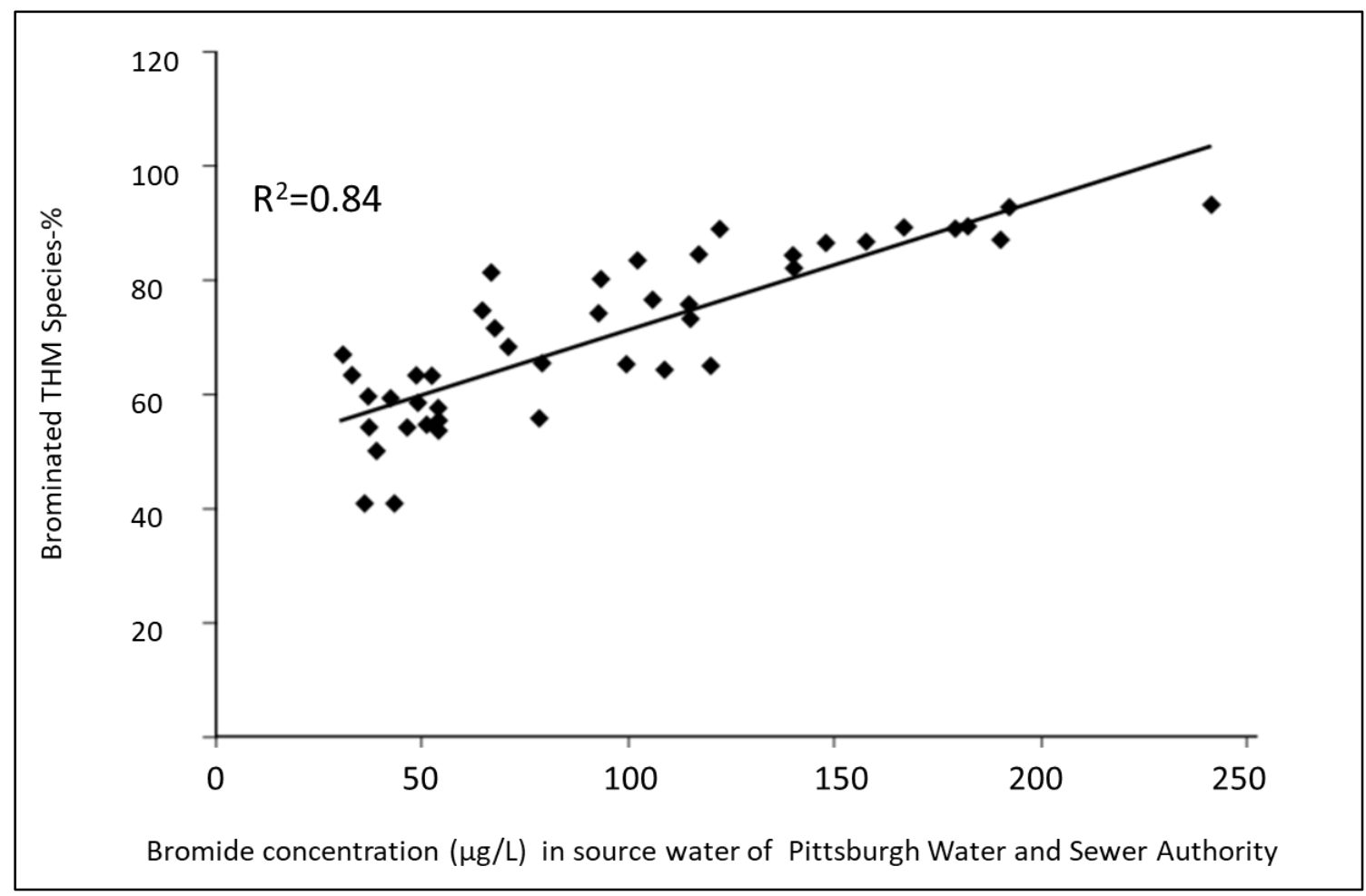

Figure 2-2 Correlation of the percentage of brominated THMs in Pittsburgh Water and Sewer Authority's finished water and bromide concentrations at the intake in Allegheny River (States et al. 2013).

Bromoform was reported as the major THM species, followed by dibromochloromethane and dichlorobromomethane with bromide sufficiently present in the water (Nikolaou 2004). Increased bromide levels were also reported to increase the concentrations of THMs in the finished water (Huang, Chen, and Wang 2019). Therefore, elevated bromide levels impact not only the individual THM species distribution but also the total concentration of THMs.

\subsection{Kinetics of THMs Formation}

THMs formation kinetics and its activation energy were examined by Masoud et al. (2019) and pseudo first-order rate constants for various THM species were on the order of $10^{-5} \mathrm{~s}^{-1}$ with an activation energy ranging from 28.5 to $30.2 \mathrm{~kJ} \mathrm{~mol}^{-1}$ (Table 2-1). The data show that the rate 
constant for chloroform was higher than other THM under the same experimental conditions. Thereby in absence of high bromide level, the chloroform concentration is expected to be the highest among the formed THMs. The Gibbs free energy was calculated at $25^{\circ} \mathrm{C}$ using the difference of internal energy and temperature times entropy for the THM fell. The values of the Gibbs free energy for all THMs fell in the range of 99-100 kJ/mol.

Table 2-1: Psuedo first-order rate constants $(K)$ for THMs formation at various temperature and activation energies (Masoud, Ismail, and El-Hoshy 2019)

\begin{tabular}{lcccc}
\hline Parameters & Chloroform & Bromodichloromethane & Dibromochloromethane & Total trihalomethane \\
\hline $\mathrm{k}\left(\mathrm{s}^{-1}\right) 10^{\circ} \mathrm{C}$ & $1.3 \times 10^{-5}$ & $1.3 \times 10^{-5}$ & $8.9 \times 10^{-6}$ & $1.27 \times 10^{-5}$ \\
$\mathrm{k}\left(\mathrm{s}^{-1}\right) 20^{\circ} \mathrm{C}$ & $1.9 \times 10^{-5}$ & $1.9 \times 10^{-5}$ & $1.2 \times 10^{-5}$ & $1.87 \times 10^{-5}$ \\
$\mathrm{k}\left(\mathrm{s}^{-1}\right) 30^{\circ} \mathrm{C}$ & $3.1 \times 10^{-5}$ & $2.6 \times 10^{-5}$ & $1.6 \times 10^{-5}$ & $2.85 \times 10^{-5}$ \\
$\mathrm{k}\left(\mathrm{s}^{-1}\right) 40^{\circ} \mathrm{C}$ & $4.5 \times 10^{-5}$ & $3.4 \times 10^{-5}$ & $2.1 \times 10^{-5}$ & $3.99 \times 10^{-5}$ \\
$\mathrm{Ea}\left(\mathrm{kJ} \mathrm{mol}^{-1}\right)$ & $30.2 \pm 1.2$ & $24.4 \pm 1.2$ & $21.4 \pm 0.3$ & $28.5 \pm 0.7$ \\
\hline
\end{tabular}

\subsection{Effects of Treatment Processes on THMs formation}

Platikanov et al. (2012) found that THMs formation took place at three distinct locations of a water treatment plant in Barcelona: after pre-chlorination, after carbon filter and post chlorination stage. NOM in the water was identified as the main cause for the DBPs formation, indicating the importance to remove NOM by the water treatment process before chlorination. Some preferential pre-treatment methods for NOM removal are coagulation, activated carbon, and resins (Figure 23, Bergman 2016). 

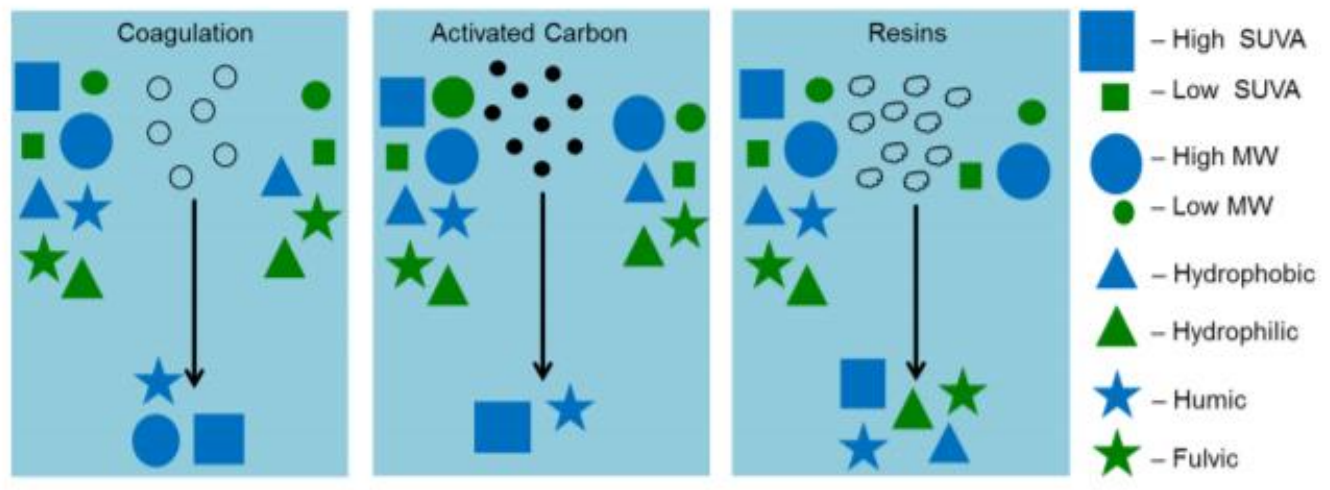

Figure 2-3: Illustration of removal of NOM fractions by various pretreatment processes adopted from Bergman (2016).

In general, coagulation preferentially removes aromatic, high molecular weight and humic fractions of the organics. Alum coagulation of humic acid prior to chlorination was found to reduce not only the TOC concentration by $86 \%$ but also chloroform concentration by more than $70 \%$ (Babcock and Singer 1979). Therefore, coagulation before the addition of chlorine can result in a substantial reduction in the amount of THMs. Though the coagulation with sorbents such as powder activated carbon (PAC) or anion exchange resin may remove NOM, may not be effective against the NOM removal associated with fouling.

In order to improve the process of coagulation, pre-oxidation of the water with chlorine or chlorine dioxide could be used in the water treatment plant to control biological growth and oxidation of metal ions although that may increase DBPs. Some water authorities have incorporated alternative disinfectant chloramine which forms less THMs than chlorination. A survey consisting 246 utilities in the U.S. during 2004, 29\% of the investigated water systems were using chloramines for secondary disinfection and another $3 \%$ were in the process of converting to chloramines (Seidel et al. 2005). 


\section{CHAPTER 3 : METHODOLOGY}

\subsection{Site description}

Three water authorities in Southwestern Pennsylvania: Borough of Charleroi Water Authority, Tri County Joint Municipal Authority and Southwestern Pennsylvania Water Authority utilizing Monongahela river as source water were selected for this study. All of these treatment plants serve at least 10,000 people. Some of these water utilities were previously sampled by WVWRI during multistate water monitoring project: Three Rivers QUEST in 2016 and the continuation of the sampling has helped to keep record of the source water quality. Water samples were collected directly from the intake to evaluate the DBP precursor level in the water. Additionally, two points in the distribution network of the finished water from both the Borough of Charleroi Water Authority (CH1 and CH2), and Tri County Joint Municipal Authority (TC1 and TC2) were sampled, and additionally one point for the Southwestern Pennsylvania Water Authority (SW3) was sampled. All the sampling points located upstream of public service district drinking water intakes and throughout the distribution network are shown in Figure 3-1.

\subsection{Sample Collection}

All the water samples were collected on a monthly basis following proper EPA and USGS approved methods for sample collection to ensure congruity and accuracy. Moreover, WVWRI has a Standard Operating Procedures (SOP) outline for proper methods for water sample collection which was also followed diligently. The SOP is a compilation of the Environmental Protection Agency's (EPA) Standard operation procedures: Surface Water Sampling and Sampling Ambient Water Quality for Determination of Metals at EPA Water Quality Criteria Levels. 


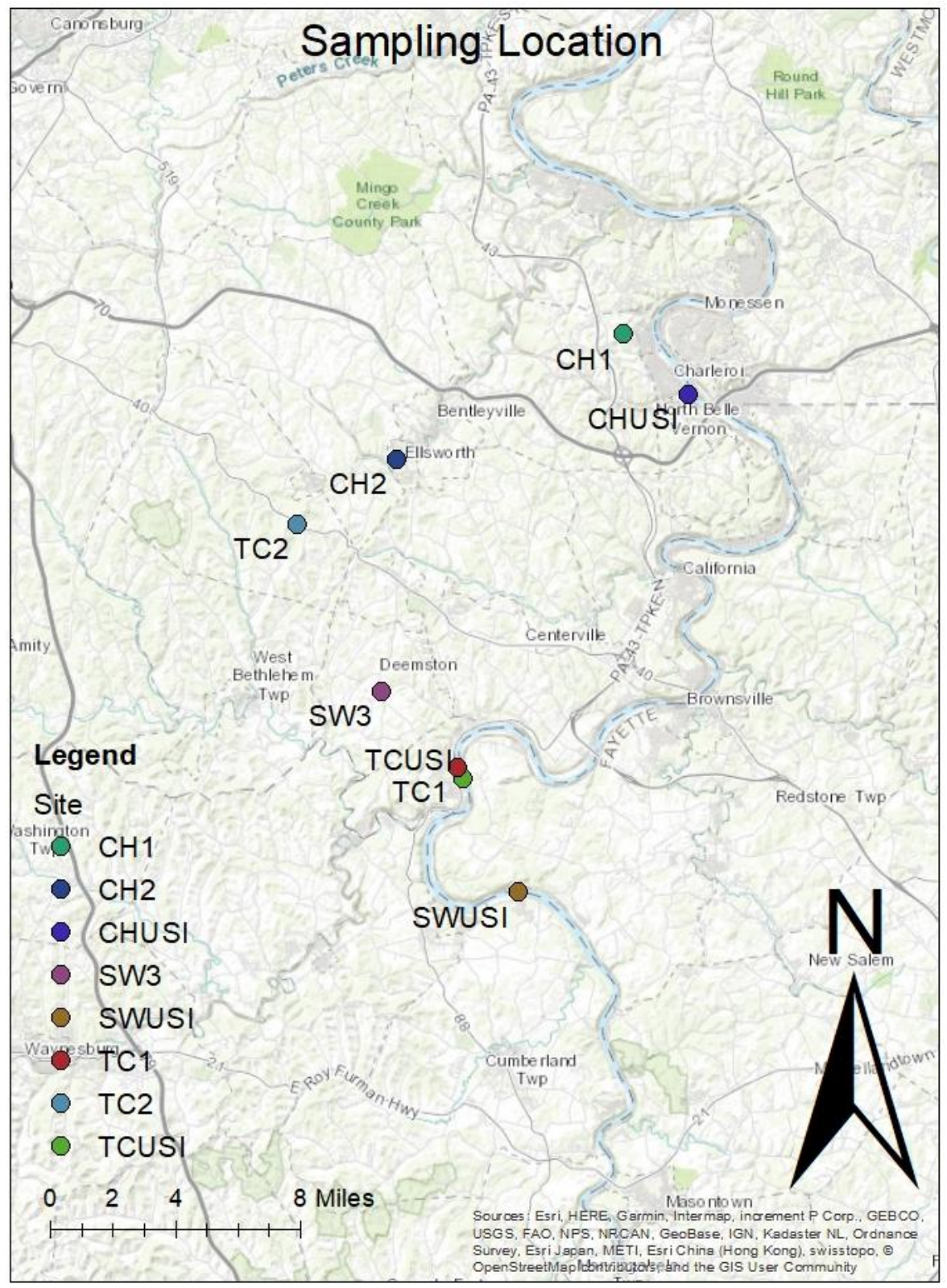

Figure 3-1: Sampling locations for the studied water treatment plants and distribution networks.

The sampling time started from September 2018 till May 2019. Chilled grab samples from the source water were analyzed for TOC, bromide, and chloride. The collected samples were sent to the laboratory and all these analyses were conducted by Pace Analytical Services in accordance with Environmental Protection Agency standardized method. In addition, a YSI multiparameter 
instrument was also used to collect field measurements for temperature, $\mathrm{pH}$, conductivity, TDS and dissolved oxygen.

\subsection{Data Analytics}

The data analytics in this study was performed in a systematic and sequential way. Pearson's correlation was first determined to access the baseline conditions of the source water quality. After checking the collinearity among the parameters, regression models were developed to predict THMs. Sensitivity analysis was conducted to identify water quality parameters that significantly affected THMs formation. In addition, bromine substitution factor (BSF) factor was calculated to access the bromine incorporation.

\subsubsection{Pearson's Correlation}

The strength of linear relationship between two variables can be determined by the Pearson's correlation. The correlation coefficients were determined for the source water quality parameters (e.g. temperature, EC, TDS, DO, bromide and chloride levels). When there exists a high correlation, the linear regression's estimates will become unreliable. Thereby, the collected data were examined by the Pearson's Correlation to the validity of implementing linear regression.

\subsubsection{Regression Based Model}

Multivariate regression (MLR) analysis is a common method for developing statistical predictive models. If $y$ is the response variable and $x_{1}, \ldots, x_{m}$ are the predictor variables, a multiple linear regression model can be expressed as

$$
y=\beta_{0}+\beta_{1} x_{1}+\beta_{2} x_{2}+\cdots+\beta_{m} x_{m}+\epsilon
$$


In our study, linear regression was applied to examine the relationships between water quality parameters and TTHMs level in the finished water. Scatter plots and bar charts were also used to visually summarize the concentration and variations of the water quality data. In addition, another model was developed using nonlinear regression following Minear and Morrow (1983). The model was developed using Minitab, a statistical analytical system program for nonlinear modeling (2019, Minitab LLC). By default, Minitab uses the Gauss-Newton method to determine the least squares estimation. The method uses a linear approximation to the expectation function to iteratively improve an initial guess, and then the method keeps improving the estimates until the relative offset falls below a prescribed tolerance.

\subsubsection{Bromine Incorporation in THM}

Brominated THMs are heavier than the chlorinated analogs and thereby incorporation of bromine increases the likelihood of exceeding the THMs level if present in the same molar amount. Gould et al. (1981) developed a dimensionless bromine incorporation factor (BIF) to calculate the percent of brominated THMs. As an alternative to BIF, another factor named bromine substitution factor (BSF) was developed by the Hua et al. (2006) which normalized BIF values to 0 to 1 . BSF was calculated for the source waters in this study using the following formula

$$
B S F=\frac{1 \times\left[\mathrm{CHCl}_{2} \mathrm{Br}\right]+2 \times\left[\mathrm{CHClBr}_{2}\right]+3 \times\left[\mathrm{CHBr}_{3}\right]}{3 \times\left(\left[\mathrm{CHCl}_{2} \mathrm{Br}\right]+\left[\mathrm{CHClBr}_{2}\right]+\left[\mathrm{CHBr}_{3}\right]+\left[\mathrm{CHCl}_{3}\right]\right.}
$$

\subsubsection{Sensitivity Analysis}

Both the linear and nonlinear models were subject to sensitivity analysis to assess sensitivity of the model outputs to water quality parameters. The distribution of individual source water quality 
parameters was first analyzed, and Weibull distribution (Weibull 1951) matched the data more appropriately than normal distribution according to Kolmogorov-Smirnov (KS ) test and p value. Fifty thousand $(50,000)$ simulations were then run with parameter values sampled from individual Weibull distributions using the Monte Carlo method (Companion by Minitab 5.3, Minitab LLC). The resultant distributions of the model outputs were plotted and compared.

\subsection{Borough of Charleroi Treatment Practices}

The Authority of Borough of Charleroi water treatment plant was constructed in early 1900's and has gone under major renovations over the years. This plant uses surface water and obtains it from the west bank of Monongahela River in Washington County. Upstream of the intake, the river drains lot of watershed containing industrial plants, residential areas with on-lot sewage system, roads, communities with sewage treatment plants, and areas of deep and surface mine that can easily impact the water quality characteristics. Multiple barrier approaches have been included in this plant to protect consumers against pathogen contamination. It operates 24 hours a day and produces averagely around 3.4 MGD on daily basis.

The plant engages multiple treatment processes in a series to remove turbidity, protozoan cysts and other microorganisms. The produced water turbidity level needs to be less 0.15 NTU and disinfectant has to be effective for $>1 \log$ inactivation of Giardia cysts according to the Pennsylvania Filtration Rule. The plant uses direct filtration method along with chemical treatment to improve the water quality. The plant implements multiple barriers so that microorganisms can easily be removed while passing from one step to another. The multiple barrier approaches undertaken at Charleroi are chemical treatment, coagulation, flocculation, microfiltration and disinfection (Figure 3-2). The water collection begins at the intake pier chamber when the water 
from the Monongahela river passes though the screen before the pier. Then the water flows into the wet well from the connected chamber. At this point, pumped water from the wet well is treated with potassium permanganate and a coagulant by mixing through two static mixers. The coagulated water then kept in the pre sedimentation tank for particle removal. The water then passes through 250-micron screen and enters the mixing tanks containing a fixed speed vertical shaft paddler mixer.

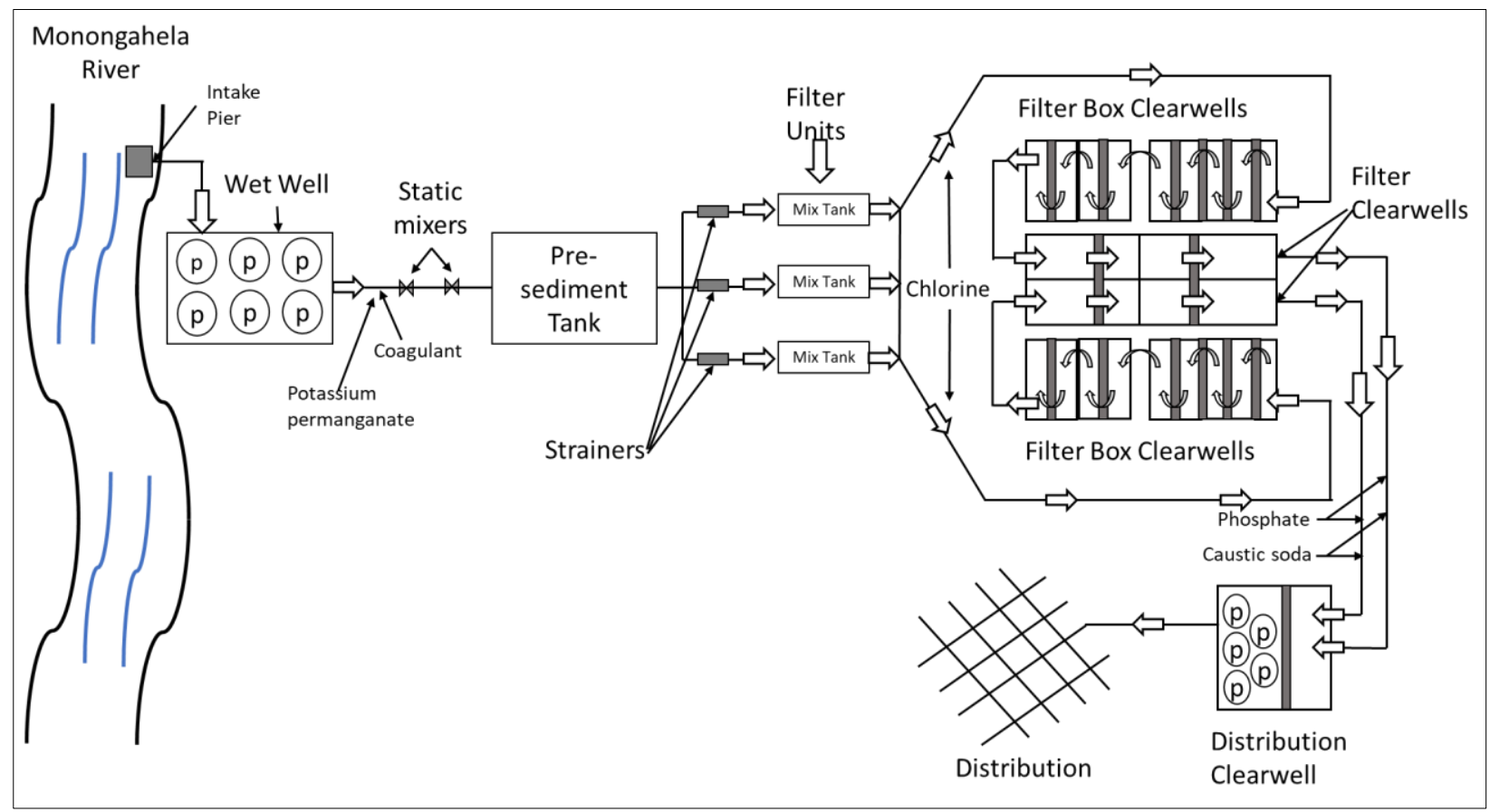

Figure 3-2: Schematic of Charleroi water treatment plant

After flocculation, the water passes through the filter units which consist of membrane filter cassettes. The water is pulled through the membranes by vacuum pumps. The filtered water is then disinfected with chlorine and discharged to a series of filter box clear wells. In the last stage, water in the effluent lines from clear well is treated with phosphate and caustic soda. The finished water is stored in a distribution clear well before pumped to the distribution system. 
Treatment related data were collected from the Borough of Charleroi Water Authority which included the daily chlorine dose added for the water treatment, quarterly organic carbon test in raw water, and quarterly THMs levels in the finished water according to the DBPRs. Additional analyses were conducted to investigate the controlling factors for TTHMs formation. 


\section{CHAPTER 4 : RESULTS AND DISCUSSION}

\subsection{Baseline conditions of source waters}

The sampling period for the study started in Fall 2018 and continued till Spring 2019. As the D/DBP rule uses a quarterly running annual average, the source water quality characteristics were shown according to seasonal variations. Table 4-1 lists the averages and standard deviations of monitored water quality parameters for autumn (September to November), winter (December to February), and spring (March to May).

Table 4-1: Seasonal averages and standard deviations of source water quality parameters

\begin{tabular}{|l|c|c|c|c|c|c|}
\hline & \multicolumn{2}{|c|}{ Autumn } & \multicolumn{2}{c|}{ Winter } & \multicolumn{2}{c|}{ Spring } \\
\hline Variable & Mean & St. Dev & Mean & St. Dev & Mean & St. Dev \\
\hline Temp ${ }^{\circ} \mathrm{C}($ Field) & 13.5 & 6.8 & 5.1 & 0.9 & 13.7 & 4.1 \\
\hline EC (Field) $\mu$ S/cm & 154 & 61 & 160 & 19.3 & 244 & 51.2 \\
\hline TDS (Field) mg/L & 141 & 22.8 & 167 & 21.1 & 179 & 31.6 \\
\hline DO mg/L (Field) & 13.7 & 3.3 & 16.8 & 3.1 & 11.9 & 1.5 \\
\hline pH (Field) & 8.2 & 0.6 & 7.9 & 0.51 & 7.7 & 0.20 \\
\hline Bromide mg/L & 0.03 & 0.01 & 0.02 & 0.02 & 0.03 & 0.01 \\
\hline Chloride mg/L & 6.0 & 1.8 & 8.4 & 2.5 & 8.8 & 2.4 \\
\hline TOC mg/L & 2.4 & 0.7 & 1.7 & 0.3 & 1.8 & 0.5 \\
\hline
\end{tabular}

Information Collection Rule (ICR) (USEPA 1996) was implied to collect data from 296 public water systems each serving at least 100,000 people from July 1997 to December 1998. Comparing these datasets with the ICR derived data ( $\mathrm{Li}$ et al. 2014), the levels of bromide in the source water seem pretty consistent whereas the TOC values were comparatively lower than the previous records.

In order to check if there exists any correlation among the parameters, correlation matrix was calculated for those parameters using the Pearson's method (Table 4-2). Statistically, when the p- 
value is less than 0.05 , the correlation becomes significant. All the derived significant correlations were consistent with the existing trend ( $\mathrm{Li}$ et al. 2014, Chowdhury 2018). The DO level showed a strong negative correlation with the field temperature $(p=0.005)$ as the DO concentration is largely influenced by the temperature. The correlation value of TOC with temperature showed a positive relationship indicating that seasonal variation plays an important role in TOC level. Generally, the high salinity increases the conductivity. During photosynthesis, aquatic plant removes carbon dioxide from water which may rise the both $\mathrm{pH}$ and $\mathrm{DO}$ in the water (Zang et al. 2011). The DO level was negatively correlated with TOC, which indicates during summer when both the TOC and temperature will be higher, it will result in lower DO.

Table 4-2: Correlation matrix for source water quality parameters

\begin{tabular}{|c|c|c|c|c|c|c|c|}
\hline & $\begin{array}{c}\text { Temp } \\
\text { (Field) } \\
{ }^{\circ} \mathbf{C}\end{array}$ & $\begin{array}{c}\text { EC (field) } \\
\mathbf{\mu S / c m}\end{array}$ & $\begin{array}{c}\text { TDS } \\
\text { (Field) } \\
\mathbf{m g} / \mathbf{L}\end{array}$ & $\begin{array}{c}\text { DO } \\
\text { (Field) } \\
\mathbf{m g} / \mathbf{L}\end{array}$ & $\mathbf{p H}$ (field) & $\begin{array}{c}\text { Bromide } \\
\mathbf{m g} / \mathbf{L}\end{array}$ & $\begin{array}{c}\text { Chloride } \\
\text { mg/L }\end{array}$ \\
\hline EC (field) $\mu \mathrm{S} / \mathrm{cm}$ & 0.33 & & & & & & \\
$p$-value & 0.098 & & & & & & \\
\hline TDS (field) $\mathrm{mg} / \mathrm{L}$ & -0.15 & $\mathbf{0 . 7 1}$ & & & & & \\
$p$-value & 0.448 & $\mathbf{0 . 0 0 0 5}$ & & & & & \\
\hline DO (field) mg/L & $\mathbf{- 0 . 7 7}$ & -0.33 & 0.14 & & & & \\
$p$-value & $\mathbf{. 0 0 0 5}$ & 0.094 & 0.477 & & & & \\
\hline pH (field) & -0.21 & -0.28 & -0.22 & 0.38 & & & \\
$p$-value & 0.284 & 0.152 & 0.277 & 0.050 & & & \\
\hline Bromide mg/L & 0.03 & 0.27 & 0.29 & 0.26 & 0.33 & & \\
$p$-value & 0.876 & 0.174 & 0.148 & 0.185 & 0.089 & & \\
\hline Chloride $\mathrm{mg} / \mathrm{L}$ & -0.45 & 0.41 & $\mathbf{0 . 6 2}$ & 0.20 & -0.26 & 0.24 & \\
$p$-value & 0.018 & 0.035 & $\mathbf{0 . 0 0 1}$ & 0.330 & 0.190 & 0.221 & \\
\hline TOC $\mathrm{mg} / \mathrm{L}$ & $\mathbf{0 . 6 5}$ & -0.08 & -0.32 & $\mathbf{- 0 . 5 6}$ & -0.14 & -0.22 & $\mathbf{- 0 . 4 1}$ \\
$p$-value & $\mathbf{0 . 0 0 0 5}$ & 0.684 & 0.103 & $\mathbf{0 . 0 0 2}$ & 0.483 & 0.269 & $\mathbf{0 . 0 3 5}$ \\
\hline
\end{tabular}

\subsection{Linearization of TOC on THM}

NOMs are usually quantified in terms of dissolved organic carbon (DOC) which is the filtered fraction of TOC through a $0.45 \mu \mathrm{m}$ membrane (Tak and Vellanki 2018). In this study, TOC was used as a surrogate for NOM. The results showed that TOC concentration of the intake water of three water authorities positively correlated with TTHMs formed in the finished water (Figure 4- 
1). The correlation improved when the data were plotted for individual treatment facility. The results suggest that THM formation potential varies with the treatment practices of the individual facility.

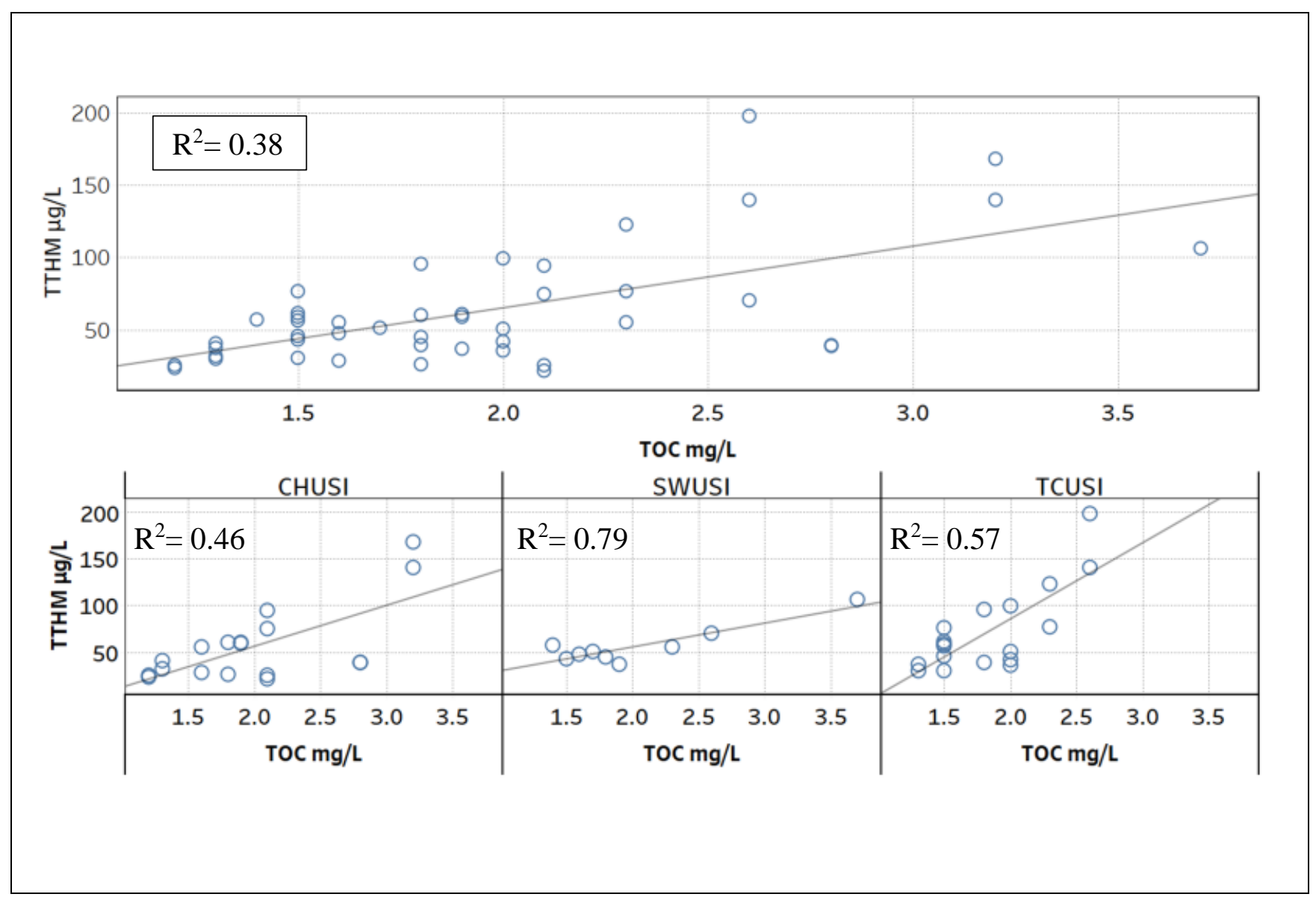

Figure 4-1: TOC concentration in the source waters vs TTHMs in the finished water at the three water treatment plants (September 2018 to May 2019).

The TOC concentration of the intake water was found to vary significantly with seasons (Figure 4-2). The concentration was higher during the months of September and October when the temperature was also higher than the other months. The highest value of TOC, $3.2 \mathrm{mg} / \mathrm{L}$, was found at Southwestern Pennsylvania Water Authority in September. There were slight increases 
in temperature during March, April, and May, but the TOC levels were still lower than the those in September.

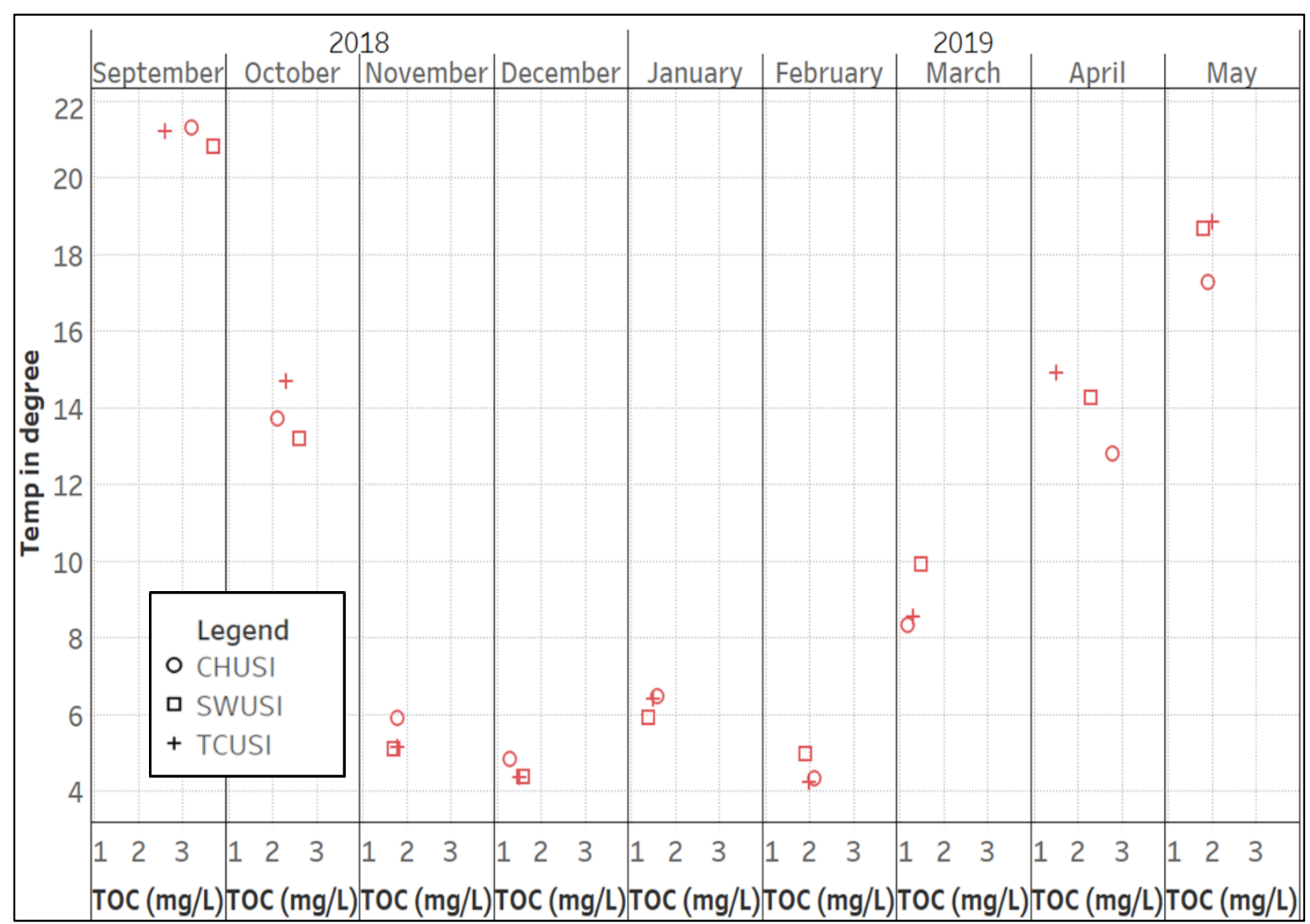

Figure 4-2: Variations in TOC level of intake water with monthly temperature.

TTHM concentration in the distribution network of Borough of Charleroi Water Authority and Tri County Joint Municipal Authority exceeded the TTHM limit during September and October. Though the TTHM was greater than $80 \mu \mathrm{g} / \mathrm{L}$ in SW3 in September, the value was comparatively lower than the TC and CH (Figure 4-3). TC2 had TTHM level of $122 \mu \mathrm{g} / \mathrm{L}$ and $99 \mu \mathrm{g} / \mathrm{L}$ respectively during the month of November and May which resulted in violation of maximum limit of TTHM at that location. For the rest of the months from 2018 till May 2019 there was no 
case of violation in any other sampling locations. But usually in TC2 the concentration was higher than rest of the locations.

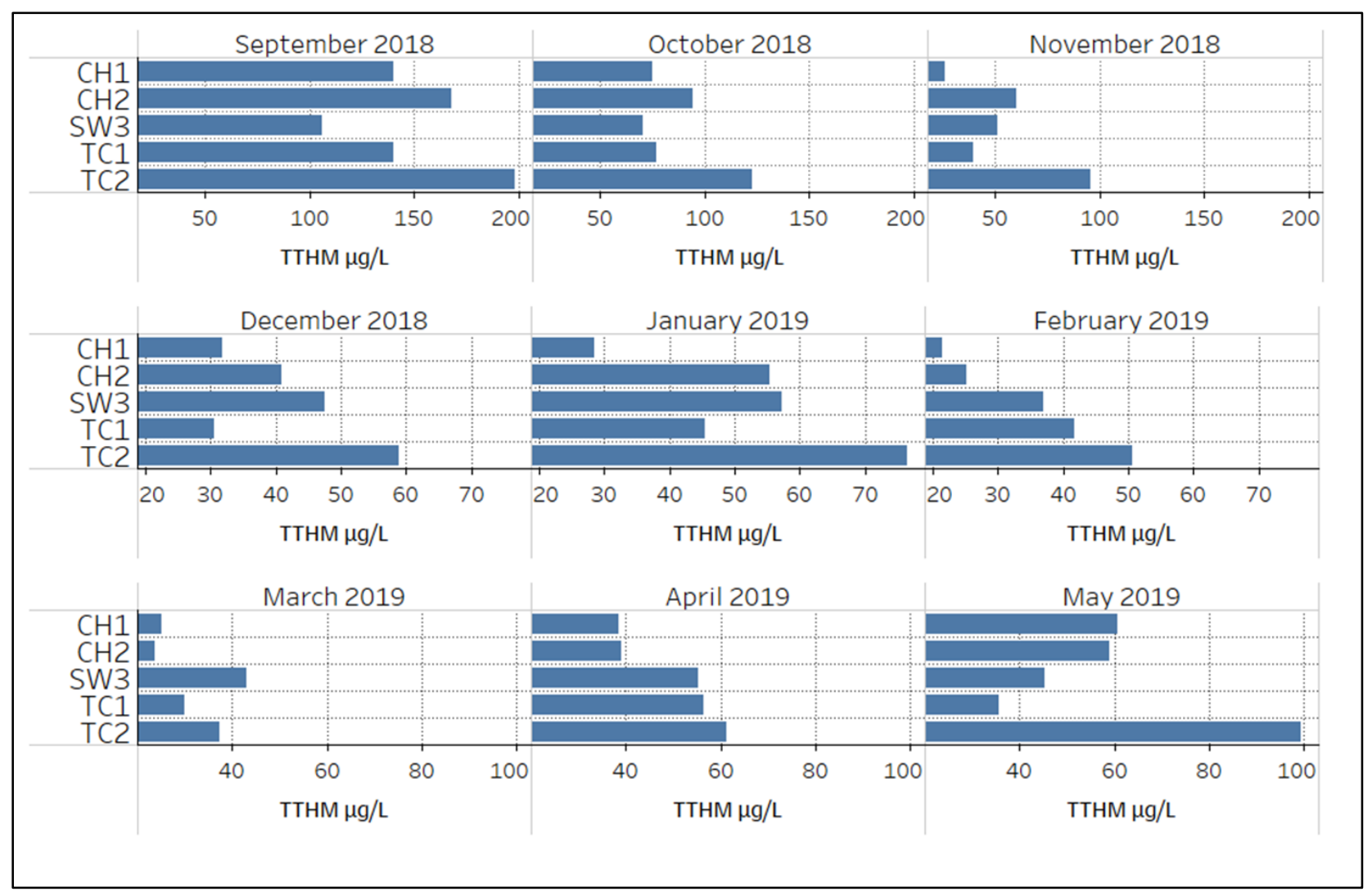

Figure 4-3: TTHM levels in the distribution networks (September 2018-May 2019)

\subsection{Distribution of THM species}

Although anthropogenic activities may cause elevated bromide in water, bromide concentration found in the United States are generally quite low, ranging from 0.014-0.2 mg/L (VanBriesen 2013). Our sampling showed that the bromide levels in the intake water were mostly below the reporting limit $(0.01 \mathrm{mg} / \mathrm{L})$. The highest bromide level was found in the intake of Tri County Joint Municipal Authority which was $0.05 \mathrm{mg} / \mathrm{L}$. 
Our data showed that bromoform was not detected in the distribution networks. Among the trihalomethanes, chloroform was the most dominant species in all the finished water samples (Figure 4-4). Dibromochloromethane was the least formed species in the samples. TC2 had the highest average chloroform concentration among the all monitored locations of the distribution networks. This is consistent with a previous study conducted by WVWRI (3RQ program) during February - October 2016.

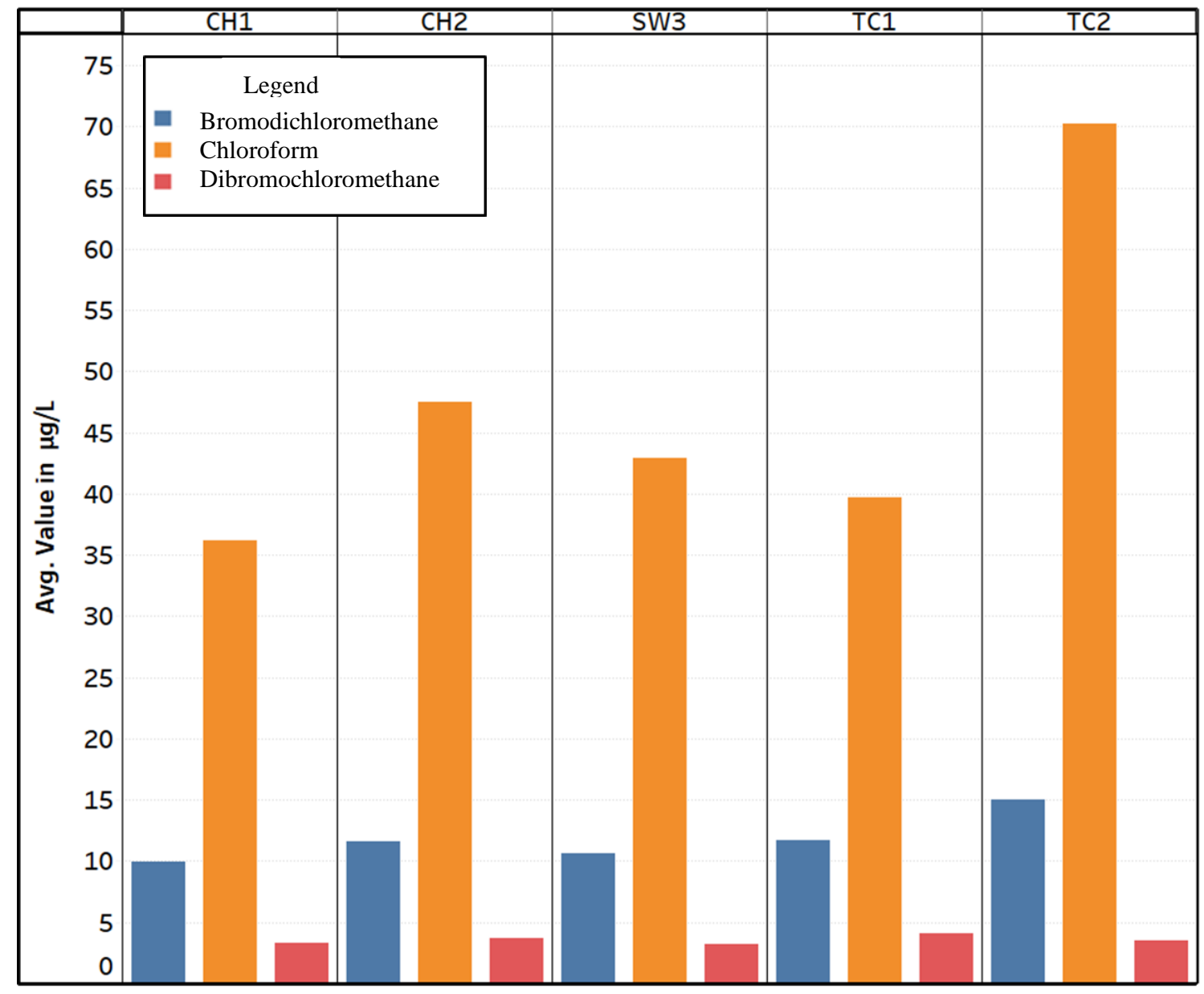

Figure 4-4 : Distribution of trihalomethane species in the finished water samples.

Despite of the lower bromide levels in the water, the BSF and substitution by mass were also determined to show the extend of bromine substitution in the THM. This BSF ranged between 0 to 0.27 . The incorporation percent of brominated species by mass ranged from 0 to $66 \%$. 


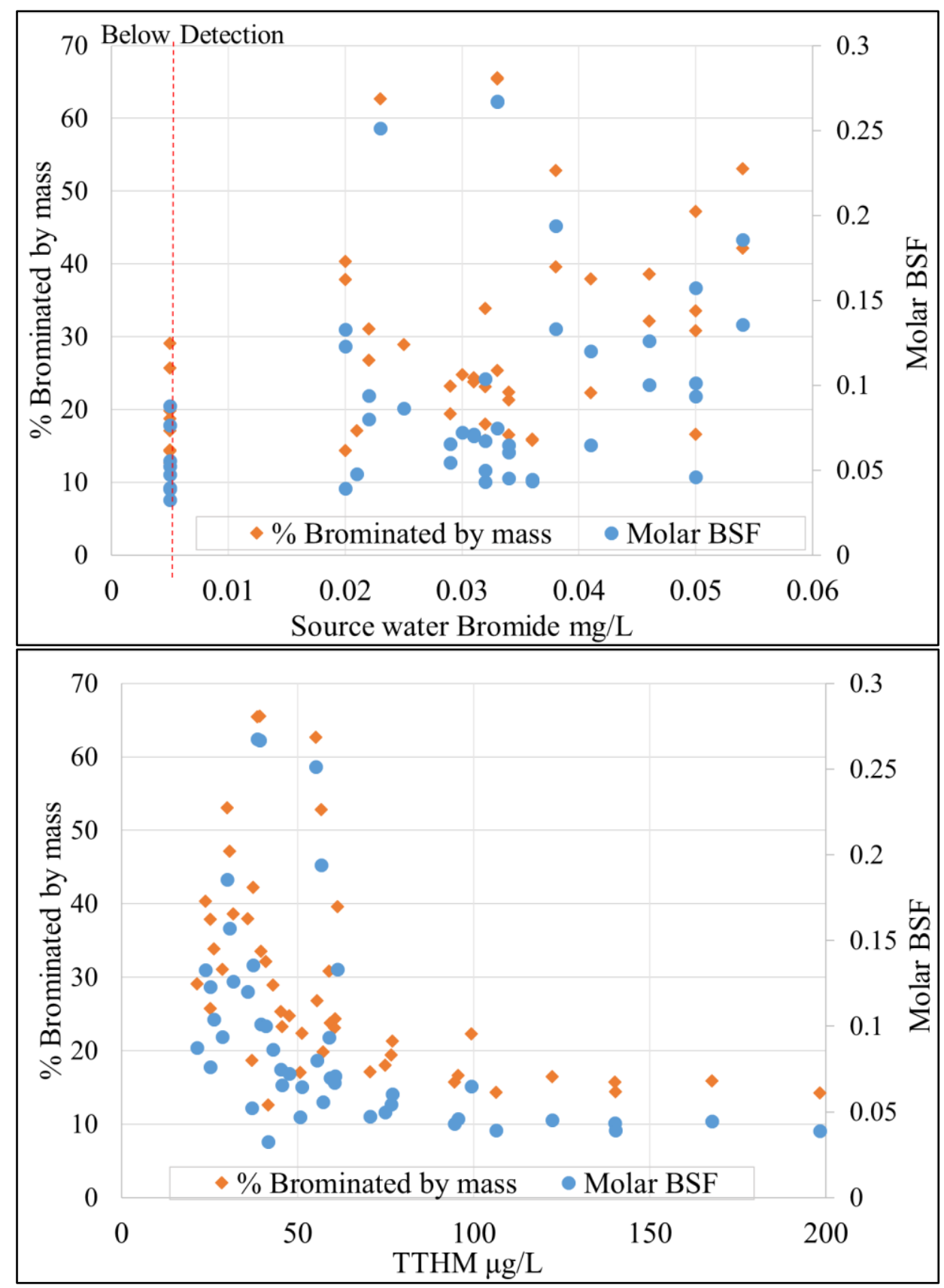

Figure 4-5: (Top) changes in BSF and \% brominated by mass with the source bromide level, and (Bottom) changes in TTHMs with BSF and \% brominated by mass.

Figure 4-5 shows that the bromine incorporation generally increased with the bromide level in source water. Nevertheless, when checked for the TTHM yield, the incorporations values were quiet low. It indicated that the chlorinated trihalomethanes were more responsible for the THMs violation in the studied distribution networks. 


\subsection{Predictive Model}

The predictors included in the models were TOC in the intake water, and chloride and temperature in the distribution network. TOC was included in the model because it directly contributes to THM formation during chlorination. Chloride concentration was used because it is related to the added chlorine to the water, and temperature represents the seasonal variation.

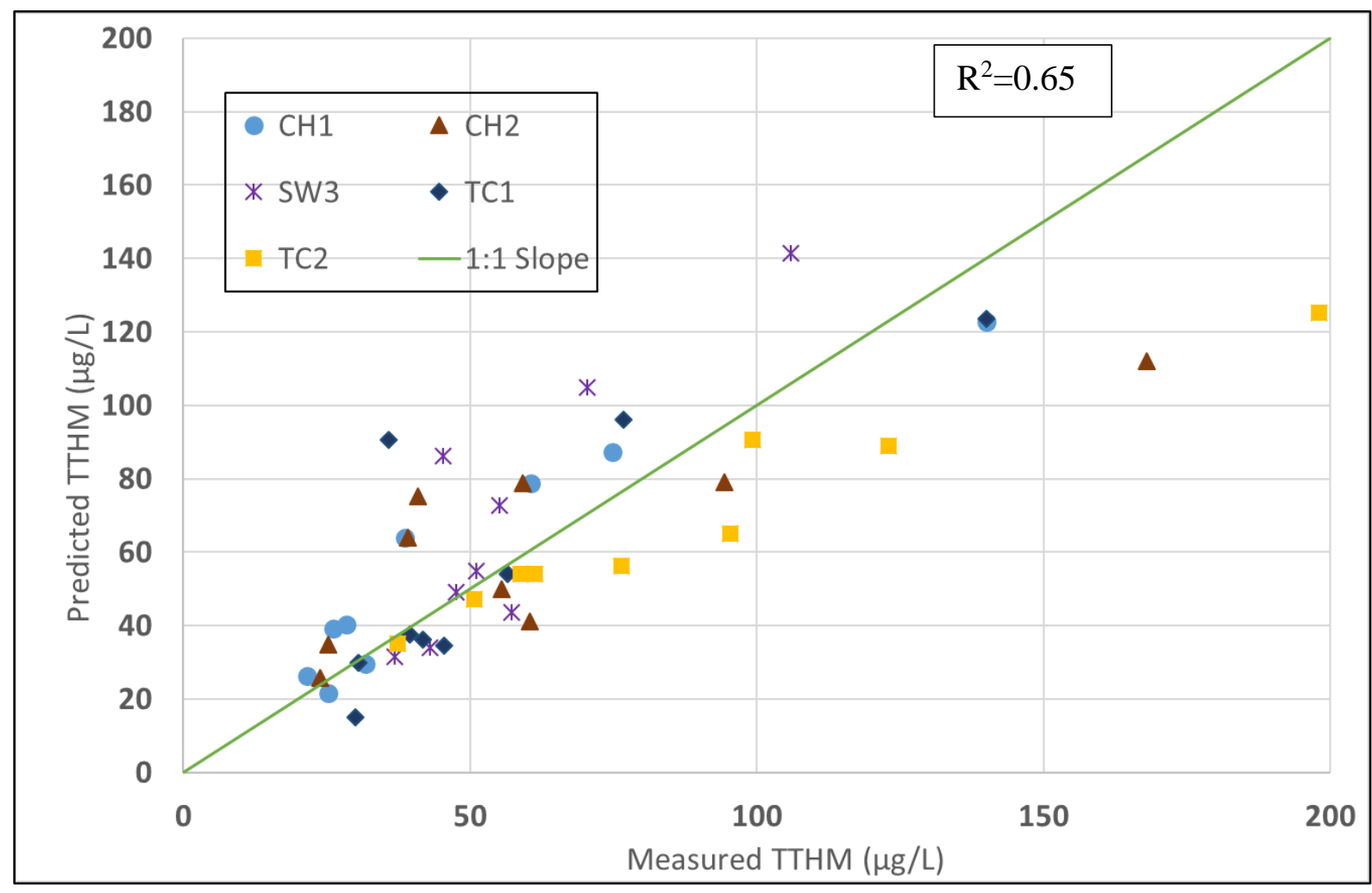

TTHM ( $\mu \mathrm{g} / \mathrm{L}):-2.95 *$ chloride $(\mathrm{mg} / \mathrm{L})+16.15 * \mathrm{TOC}(\mathrm{mg} / \mathrm{L})+4.65 * \mathrm{Temp}$ (in C) -10.52

Figure 4-6: Measured TTHMs vs the predicted TTHMs concentration for linear regression.

The predicted values were then compared with the measured values (Figure 4-6). The analysis showed that the developed model tends to underestimate the TTHM concentration when TTHM concentration are above $120 \mu \mathrm{g} / \mathrm{L}$. Inclusion of actual chlorine dose (other than chloride) and retention time may yield a better model to predict the TTHMs in the finished water. 
The monitoring data resulted in the following nonlinear regression model:

$$
\operatorname{TTHM}(\mu \mathrm{g} / \mathrm{L})=-18.72 * \log \left(\text { chloride }\left(\frac{\mathrm{mg}}{\mathrm{L}}\right)\right)+10^{0.68} * \text { Temp (in C) }+16.73 * \text { TOC }(\mathrm{mg} / \mathrm{L})
$$

By comparing the predicted values with the measured values (Figure 4-7), it is evident that the nonlinear regression model mostly overestimated the TTHM levels in all the water sampling locations. Thus, the linear regression is more suitable than the nonlinear one for predicting TTHM for those sampling points.

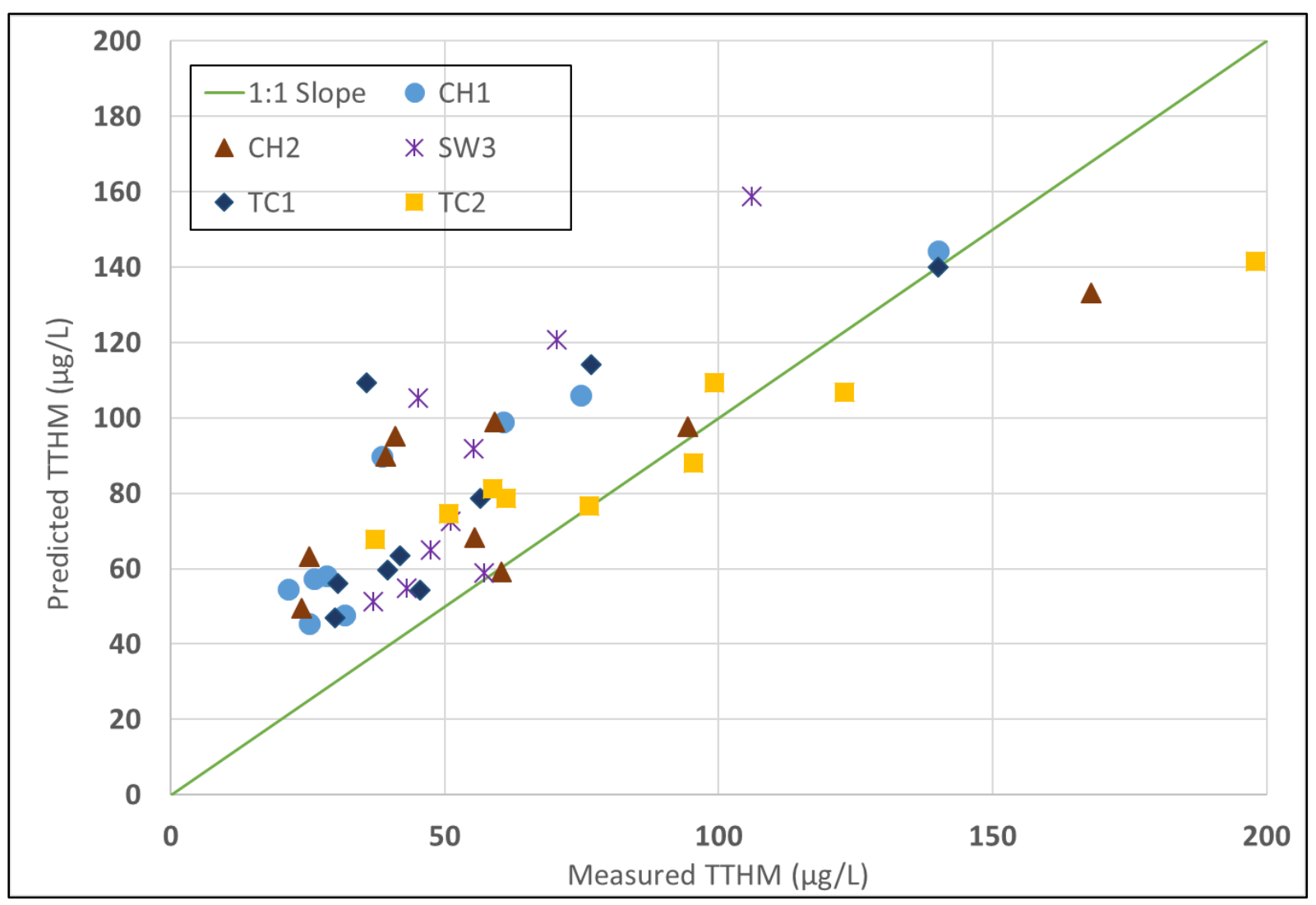

Figure 4-7: Measured TTHMs vs the predicted TTHMs concentration for nonlinear regression.

\subsection{Sensitivity Analysis}

The Monte Carlo simulations was generated to observe the sensitivity analysis along with quantifying the probability of THM violation. 


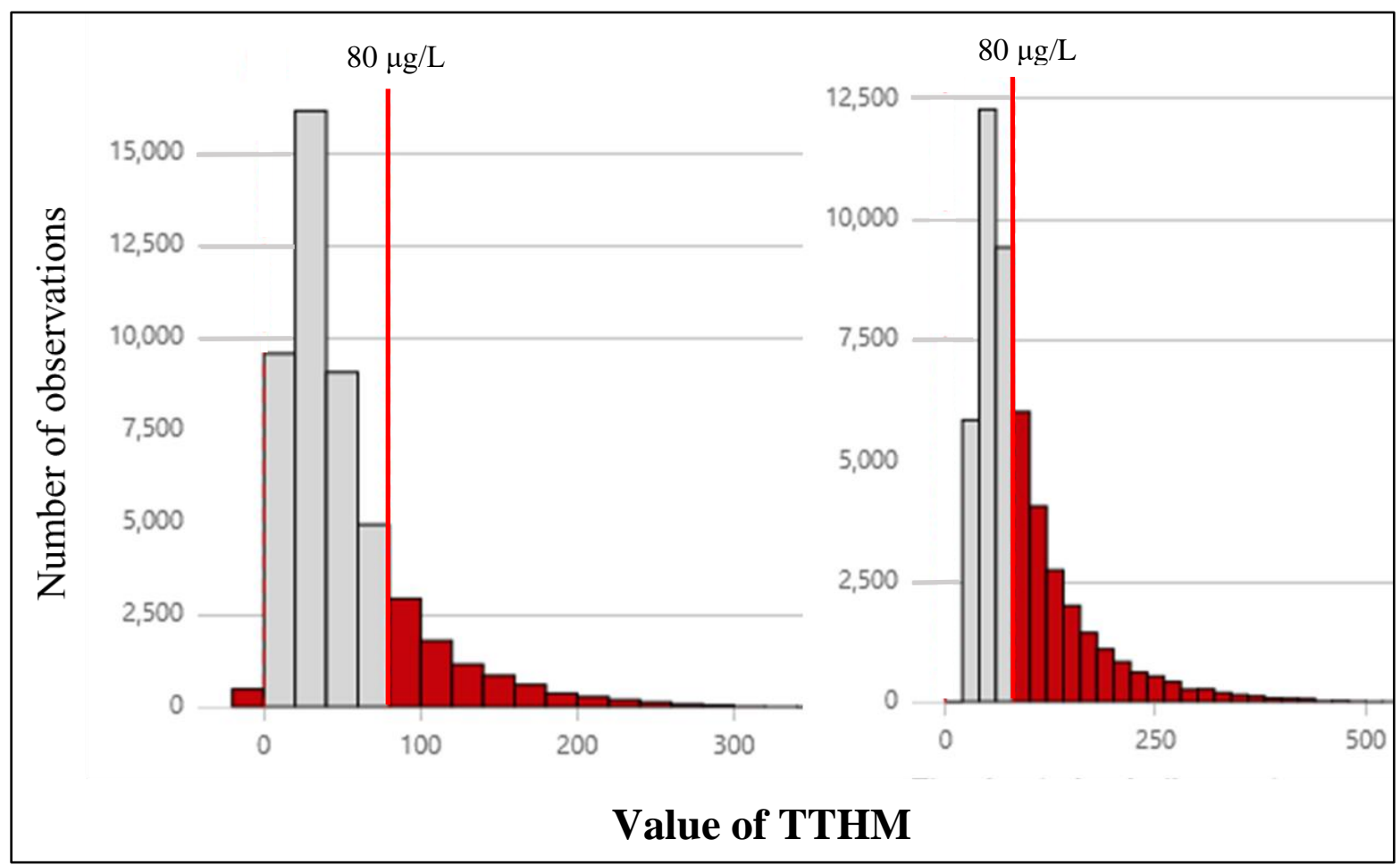

Figure 4-8: Monte Carlo simulations of THMs values falling outside of specifications limits (Left) for linear regression model and (Right) nonlinear regression model.

A range of $0-80 \mu \mathrm{g} / \mathrm{L}$ of THM was selected to observe the cases of violation. Out of 50,000 simulations, $44.7 \%$ cases TTHMs fell outside of the MCL for nonlinear regression whereas for 20\% cases TTHM fall outside of the MCL for linear regression (Figure 4-8). A summary statistic of these two simulations are given in the following table:

Table 4-3: Summary statics of the Monte Carlo simulation outputs of the two models.
Summary Statistics
Linear Regression
Nonlinear Regression

\begin{tabular}{ccc}
\hline Number of Observations & 50000 & 50000 \\
\hline Mean TTHM $(\mu \mathrm{g} / \mathrm{L})$ & 54.7 & 101.5 \\
\hline Median TTHM $(\mu \mathrm{g} / \mathrm{L})$ & 37.9 & 73.6 \\
\hline
\end{tabular}


The linear regression showed 544 cases of THM levels of negative in the simulation which is in reality not possible. For the nonlinear regression, the mean TTHM value was 101.5 and that is over the violation limit. Due to virtual assumptions, the distributions of the predictor variables were considered randomly in such a way that would hardly occur in natural surface water and hence such discrepancies might have occurred in the simulations.

The sensitivity analysis showed the same order of importance of the predictor variables for the both models:Chloride $>$ TOC $>$ Temp. Figure 4-9 and 4-10 contain the sensitivity results for the linear and nonlinear model respectively. For the linear model, the level of chlorine effect mostly aligned with the TOC and eventually changes in these two parameters had very similar effects on standard deviation of the model output. But the variation in temperature resulted in significant changes of the output standard deviation. The nonlinear regression showed the same trend, but the value of the output deviations was higher.

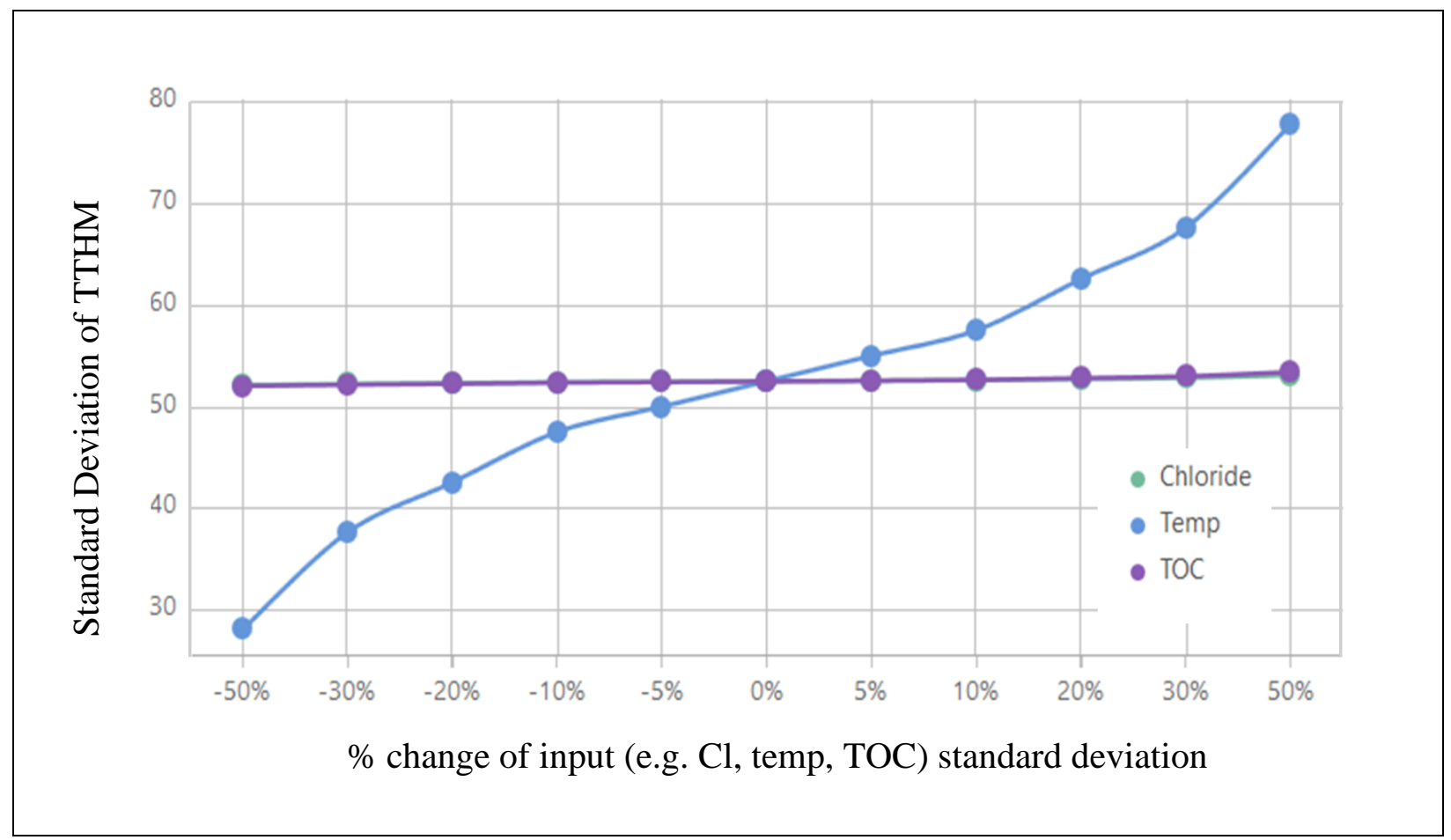

Figure 4-9: Sensitivity of the output standard deviation to the predictor variables for linear regression model. 


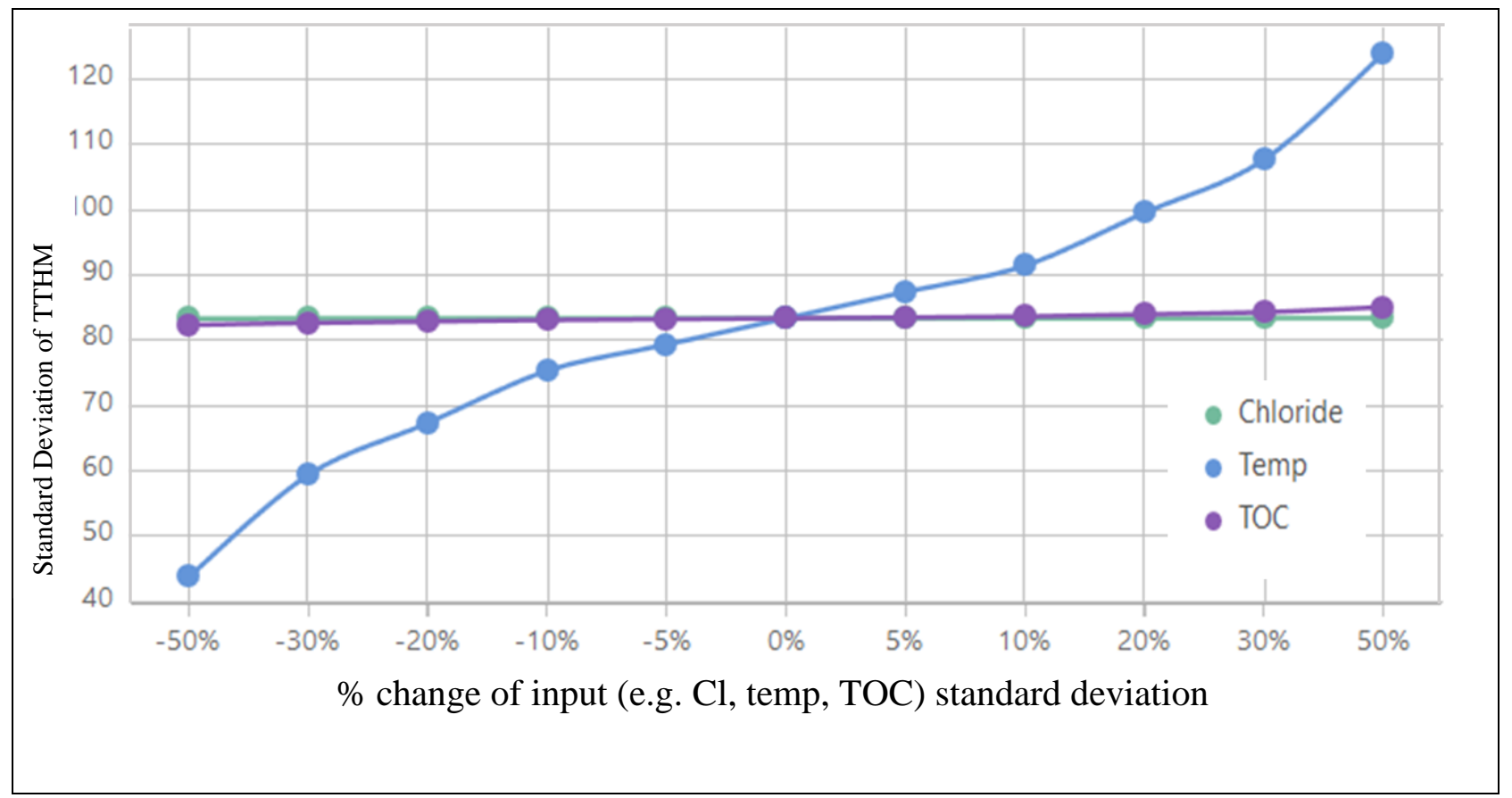

Figure 4-10: Sensitivity of the output standard deviation to the predictor variables for the nonlinear regression model.

\subsection{Effect of Prechlorination and Sedimentation tank}

Treatment practices at the Borough of Charleroi Water Authority were analyzed to investigate its effects on TTHM formation. Change of the monthly residual chlorine concentration was investigated to find whether excessive chlorine concentration existed during the late fall when the TTHM violation occurred. According to the Figure 4-11, the residual chlorine concentration was highest during September 2018 and TTHM violation occurred both in $\mathrm{CH} 1$ and $\mathrm{CH} 2$ in the same month. There was violation at $\mathrm{CH} 2$ during October as well, but the residual chlorine concentration was lower at that time. The retention time in the water system may have played a role in the violations. Pre-chlorination was undertaken by adding chlorine to the water before entering the filtration facility during the end of the December because of the low temperature. This did not cause TTHM violations, rather the chlorination helped to maintain residual chlorine in the 
distribution system during colder season. Chlorine was added into the water for the second time after passing through membrane filter unit as part of post chlorination.

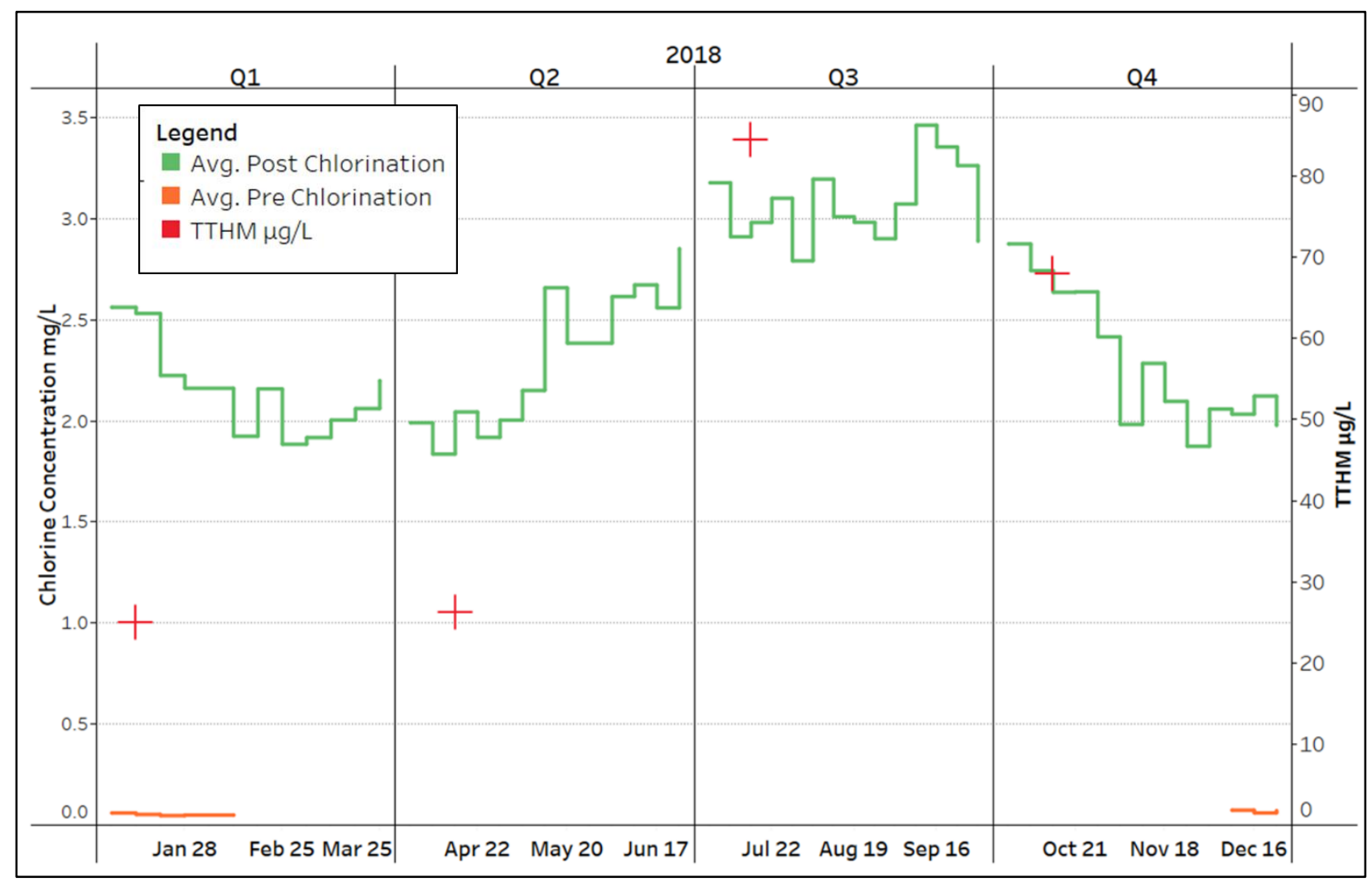

Figure 4-11: Effects of Chlorination in THM formation at the Borough of Charleroi Water Authority in 2018.

The plant is operated in a direct filtration mode and includes chemical treatment and mixing prior to microfiltration through GE/Zenon membrane modules, disinfection, and phosphate and caustic soda for distribution system corrosion control. In 2016, two sedimentation basins were used to provide additional barrier to the passage of waterborne pathogens and to reduce THM formation in the finished water. To identify the role of sediment tank, the scenario of before the installation of the sediment tank was compared to the condition after the installation (Figure 4-12). It is evident 

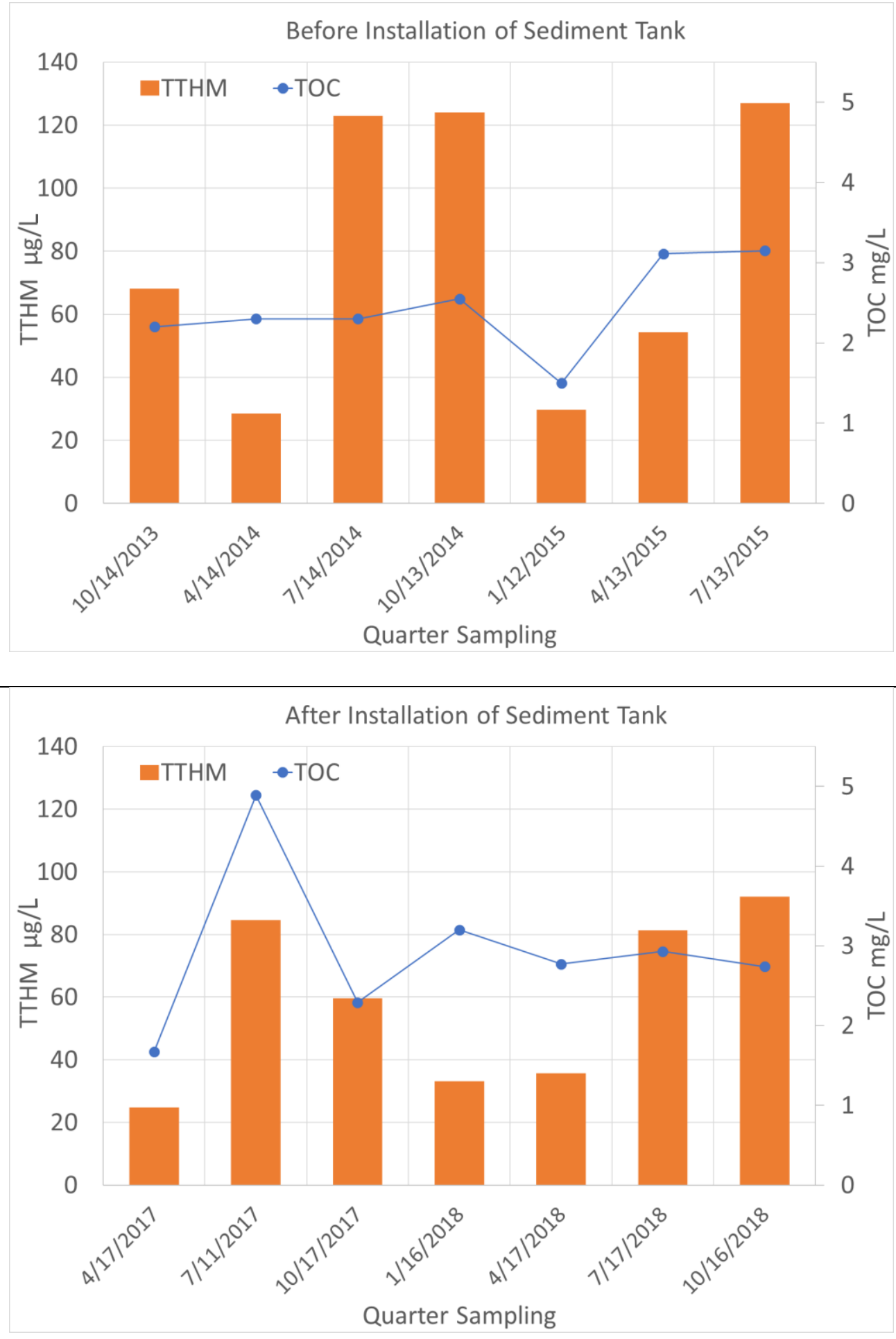

Figure 4-12: Comparison of TTHMs in the distribution network and TOC concentration in raw water before and after the installation of sedimentation tanks. 
that, before the installation, the elevated TTHM levels were in the range of $123-130 \mathrm{mg} / \mathrm{L}$ in the supplied water with TOC in the raw water ranging from 2.3 to $3.2 \mathrm{mg} / \mathrm{L}$. After the installation of the tank, TTHM concentrations were lower than those before the installation of the sedimentation tanks even with higher TOC concentrations in the intake water. Similar trends were observed at other locations (e.g. Spears Exxon and Rotolos) of the distribution network. This shows the positive impact of the installation of the sediment tanks on THM control while using membrane filter.

The Tri County Joint Municipal Authority plant has a similar treatment train except for the membrane filter; it has conventional sand filters. The treatment system seemed to cause operational exceedance due to clear well deficiencies previously and it was suggested to monitor the chlorine feed and disinfection contact time in order to maintain minimum reasonable levels of THMs (Horvat 2016). Thus, proper care should be taken to maintain required contact time (CT) along with installing baffles in reservoir for desirable baffling factor. Appropriate baffling factor helps to adjust the theoretical detention time to more realistic CT by eliminating short circuiting of water path in reservoir. Low water demand and consequently long retention time of water in the distribution network is a common reason for THMs exceedances. Flushing so that water can move through the distribution network should also be taken into consideration. The Southwestern Pennsylvania Water Authority uses chloramine during the late spring, summer, and autumn months while the other two plants continuously use chlorine as disinfectant. Though the Southwestern Pennsylvania Water Authority had highest TOC in most months, the TTHMs levels were lower than other distribution networks. This clearly shows how the change of disinfectant from chlorine to chloramine may help to reduce the formation of THMs. 


\section{CHAPTER 5: CONCLUSION}

This study aimed to aid the operators to reduce trihalomethane occurrences and levels in small and mid-size treatment plants by investigating causal linkages between the precursor levels and factors that contribute to THMs formation. This project was an attempt to develop operational guidelines to reduce the THM levels based on the source water quality and treatment practices. Several conclusions have been drawn from our analyses.

- Temperature was identified as the most significant parameter affecting THMs level given the TOC content in the source's waters. Some of the key limitations of the study include short of source water data that cover full seasonal cycle and lack of in-plant data such as TOC at different stage of the treatment train.

- The linear regression model was better than the nonlinear one for the THM prediction in the finished water of southwestern Pennsylvania authorities. This developed model can be adapted for other water utilities using plant specific data.

- As most of the violations occurred during the autumn, special optimization is warranted to keep the THM level under control. Addressing this fact and undertaking short term changes in unit operation (e.g. avoiding prechlorination during warmer season) targeting to meet regulatory compliance can be a viable solution.

- Effective coagulation and operation of sedimentation basin can provide an additional barrier to passage of waterborne pathogens as well as controlling THMs formation. 
- Practices such as minimizing perchlorinating, changing location of chlorination, introduction of chlorine boosting stations along the distribution network and using chloramines as secondary disinfectant (Farren 2003) help to reduce the THMs formation while maintaining required chlorine residual.

- Water treatment using hydrogen peroxide $\left(\mathrm{H}_{2} \mathrm{O}_{2}\right)$ in conjunction with chlorine to maintain the residual chlorine demand needs to be studied to determine the feasibility of this process for THM formation reduction. 


\section{REFERENCES}

Allaire, Maura, Haowei Wu, and Upmanu Lall. 2018. "National Trends in Drinking Water Quality Violations" 115 (9): 2078-83. https://doi.org/10.1073/pnas.1719805115.

Babcock, David B, and Philip C Singer. 1979. "CHLORINATION AND COAGULATION OF HUMIC AND FULVIC ACIDS.” J Am Water Works Assoc 71 (3): 149-52. https://doi.org/10.1002/j.1551-8833.1979.tb04318.x.

Bergman, Lauren E. 2016. "Predicting Water Treatment Challenges from Source Water Natural Organic Matter Characterization.” Carnegie Mellon University.

Bove, Gerald E, Peter A Rogerson, and John E Vena. 2007. "Case Control Study of the Geographic Variability of Exposure to Disinfectant Byproducts and Risk for Rectal Cancer." International Journal of Health Geographics 6 (1): 18. https://doi.org/10.1186/1476-072X-6-18.

Cantor, Kenneth P., Charles F. Lynch, Mariana E. Hildesheim, Mustafa Dosemeci, Jay Lubin, Michael Alavanja, and Gunther Craun. 1998. "Drinking Water Source and Chlorination Byproducts I. Risk of Bladder Cancer." Epidemiology 9 (1): 21-28. https://doi.org/10.1097/00001648-199801000-00007.

Carrell Morris, J, by J Carrell Morris, E A Shilov, J V Gladtchikova, A I Slyadnov, G V Kupinskaya, and Zh Obshchei Khim. 1922. "The Acid Ionization Constant of HOCI from 5 to 35․" J. HOye, Kgl. Norske Videnskab. Selskabs Forch. Vol. 44. H. Hagisawa. https://pubs.acs.org/sharingguidelines.

Chowdhury, Shakhawat. 2018. "Occurrences and Changes of Disinfection By-Products in Small Water Supply Systems.” Environmental Monitoring and Assessment 190 (1). https://doi.org/10.1007/s10661-017-6410-8.

Croué, Jean-Philippe. 2004. "ISOLATION OF HUMIC AND NON-HUMIC NOM FRACTIONS: STRUCTURAL CHARACTERIZATION."

Deborde, Marie, and Urs von Gunten. 2008. "Reactions of Chlorine with Inorganic and Organic Compounds during Water Treatment-Kinetics and Mechanisms: A Critical Review." Water Research. https://doi.org/10.1016/j.watres.2007.07.025.

Fair, G. M., J. C. Morssis, L.C. Chang, I. Weil, and R.P. Burden. 1949. "Behavior of Chlorine as a Water Disinfectant." Water \& Sewage Works 96 (5): 101-4. https://doi.org/10.1002/j.1551-8833.1948.tb15055.x.

Farren, Elizabeth Anne. 2003. "Reducing Trihalomethane Concentrations By Using Chloramines as a Disinfectant," no. April.

Horvat, Robert. 2016. "TTHM Reduction Corrective Action Update." https://tricountypa.org/documents/743/TCJMA_Public_Meeting_Full_101816.pdf.

Hua, Guanghui, David A. Reckhow, and Junsung Kim. 2006. "Effect of Bromide and Iodide Ions on the Formation and Speciation of Disinfection Byproducts during Chlorination." 
Environmental Science and Technology 40 (9): 3050-56.

https://doi.org/10.1021/es0519278.

Huang, Chih Hsuan, Chia Yang Chen, and Gen Shuh Wang. 2019. "Temperature Dependence of Characteristics of Organic Precursors, Bromide, and Disinfection Byproduct Formation."

Science of the Total Environment 662 (April): 746-54.

https://doi.org/10.1016/j.scitotenv.2019.01.239.

Li, Zhiwei, Robert M Clark, M Asce, Steven G Buchberger, Y Jeffrey Yang, and D Wre. 2014. "Evaluation of Climate Change Impact on Drinking Water Treatment Plant Operation." https://doi.org/10.1061/(ASCE)EE.1943-7870.0000824.

Liang, Lin, and Philip C. Singer. 2003. "Factors Influencing the Formation and Relative Distribution of Haloacetic Acids and Trihalomethanes in Drinking Water." Environmental Science and Technology 37 (13): 2920-28. https://doi.org/10.1021/es026230q.

Masoud, Mamdouh S, Amel M Ismail, and Mostafa M El-Hoshy. 2019. "Kinetics and Thermodynamics of the Formation of Trihalomethanes." Applied Water Science 9 (4): 3. https://doi.org/10.1007/s13201-019-0981-1.

Minear, Roger A., and C. M. Morrow. 1983. "Raw Water Bromide: Levels and Relationship to Distribution of Trihalomethanes in Finished Drinking Water."

Nikolaou, Anastasia D. 2004. "Investigation of the Formation of Chlorination By-Products in Water Rich in Bromide and Organic Matter Content." Journal of Environmental Science and Health - Part A Toxic/Hazardous Substances and Environmental Engineering 39 (1112): 2835-53. https://doi.org/10.1081/LESA-200033949.

Padhi, R. K., Suja Subramanian, A. K. Mohanty, and K. K. Satpathy. 2019. “Comparative Assessment of Chlorine Reactivity and Trihalomethanes Formation Potential of Three Different Water Sources." Journal of Water Process Engineering 29 (June). https://doi.org/10.1016/j.jwpe.2019.02.009.

Platikanov, Stefan, Jordi Martín, and Romà Tauler. 2012. "Linear and Non-Linear Chemometric Modeling of THM Formation in Barcelona's Water Treatment Plant." Science of the Total Environment 432 (August): 365-74. https://doi.org/10.1016/j.scitotenv.2012.05.097.

Richardson, Susan D. 2003. "Disinfection By-Products and Other Emerging Contaminants in Drinking Water." TrAC - Trends in Analytical Chemistry 22 (10): 666-84. https://doi.org/10.1016/S0165-9936(03)01003-3.

Rook, J.J. 1974. "Formation of Haloforms during Chlorination of Natural Waters." Water Treat. Exam. 23: 234-43.

Seidel, Chad J., Michael J. McGuire, R. Scott Summers, and Steve Via. 2005. "Have Utilities Switched to Chloramines?" Journal - American Water Works Association 97 (10): 87-97. https://doi.org/10.1002/j.1551-8833.2005.tb07497.x.

Singer, Philip C. 1994. "Control of Disinfection By-Products in Drinking Water." Journal of Environmental Engineering 120 (4): 727-44. https://doi.org/10.1061/(ASCE)07339372(1994)120:4(727). 
States, Stanley, Georgina Cyprych, Mark Stoner, Faith Wydra, John Kuchta, Jason Monnell, and Leonard Casson. 2013. "Marcellus Shale Drilling and Brominated THMs in Pittsburgh, Pa., Drinking Water.” Journal - American Water Works Association 105 (8): E432-48. https://doi.org/10.5942/jawwa.2013.105.0093.

Tak, Surbhi, and Bhanu Prakash Vellanki. 2018. "Natural Organic Matter as Precursor to Disinfection Byproducts and Its Removal Using Conventional and Advanced Processes: State of the Art Review." Journal of Water and Health 16 (5): 681-703. https://doi.org/10.2166/wh.2018.032.

Thompkins, Anita. 2018. "Drinking Water Protection Program Update Key Topics National Drinking Water Advisory Council (NDWAC) |."

United States Environmental Protection Agency (USEPA). 1996. "ICR Water Utility Database System User's Guide Release 1.1.” EPA 814/B-96-004A, Office of Ground Water and Drinking Water.

United States Environmental Protection Agency (USEPA). 1998. "National Primary Drinking Water Regulations: Disinfectants and Disinfection Byproducts Rule." Federal Register 63 (241): 69390-476.

United States Environmental Protection Agency (USEPA). 2006. "National Primary Drinking Water Regulations: Stage 2 Disinfectants/Disinfection Byproducts Rule." Federal Register 71 (2): 388-493.

VanBriesen, Jeanne M. 2013. "Potential Drinking Water Effects of Bromide Discharges from Coal-Fired Electric Power Plants." Formal Comments of the Environmental Integrity Project et Al. on the Effluent Limitations Guidelines and Standards for the Steam Electric Power Generating Point Source Category, Appendix B of Water Docket EPA-HQ-OW2009-0819-4687.

Villanueva, Cristina M., Kenneth P. Cantor, Sylvaine Cordier, Jouni J.K. Jaakkola, Will D. King, Charles F. Lynch, Stefano Porru, and Manolis Kogevinas. 2004. "Disinfection Byproducts and Bladder Cancer: A Pooled Analysis.” Epidemiology 15 (3): 357-67. https://doi.org/10.1097/01.ede.0000121380.02594.fc.

Weibull, W. 1951. "A Statistical Distribution Function of Wide Applicability.” Journal of Applied Mechanics 13: 293-97.

Wright, J. M., J. Schwartz, and D. W. Dockery. 2003. "Effect of Trihalomethane Exposure on Fetal Development.” Occupational and Environmental Medicine 60 (3): 173-80. https://doi.org/10.1136/oem.60.3.173.

Xue, Chonghua, Qi Wang, Wenhai Chu, and Michael R. Templeton. 2014. "The Impact of Changes in Source Water Quality on Trihalomethane and Haloacetonitrile Formation in Chlorinated Drinking Water." Chemosphere 117 (1): 251-55. https://doi.org/10.1016/j.chemosphere.2014.06.083.

Zang, Changjuan, Suiliang Huang, Min Wu, Shenglan Du, Miklas Scholz, Feng Gao, Chao Lin, Yong Guo, and Yu Dong. 2011. "Comparison of Relationships between PH, Dissolved Oxygen and Chlorophyll a for Aquaculture and Non-Aquaculture Waters." Water, Air, and 
Soil Pollution. https://doi.org/10.1007/s11270-010-0695-3.

Zhang, Haifeng, Yahe Zhang, Quan Shi, Shuoyi Ren, Jianwei Yu, Feng Ji, Wenbin Luo, and Min Yang. 2012. "Characterization of Low Molecular Weight Dissolved Natural Organic Matter along the Treatment Trait of a Waterworks Using Fourier Transform Ion Cyclotron Resonance Mass Spectrometry.” Water Research 46 (16): 5197-5204.

https://doi.org/10.1016/j.watres.2012.07.004. 